Northwestern University School of Law Northwestern University School of Law Scholarly Commons

Faculty Working Papers

2010

\title{
Can Legislatures Constrain Judicial Interpretation of Statutes?
}

Anthony D'Amato

Northwestern University School of Law, a-damato@law.northwestern.edu

\section{Repository Citation}

D'Amato, Anthony, "Can Legislatures Constrain Judicial Interpretation of Statutes?" (2010). Faculty Working Papers. Paper 71.

http://scholarlycommons.law.northwestern.edu/facultyworkingpapers/71 


\title{
Can Legislatures Constrain Judicial Interpretation of Statutes?
}

\author{
by Anthony D’Amato*, 75 Va. L. Rev. 561-603 (1989)
}

\begin{abstract}
An aspect of the battle over deconstruction is whether resort to legislative intent might help to determine the content of a statutory text that otherwise, in splendid isolation, could be deconstructed by simply positing different interpretive contexts. I examine the same issue by recounting my own quest for determinate meaning in statutes—a sort of personal legislative history. I do not claim for jurisprudence the role of ensuring faithful reception of the legislature's message, for that is impossible. At best, jurisprudential theory only reduces the degrees of interpretive freedom, and then only probably, not necessarily. The more significant thesis of this article is that all theories of statutory interpretation can only do that much and no more.
\end{abstract}

Tags: legislative intent, statutory interpretation, jurisprudence, deconstruction, doctrinalists

[pg561]** An aspect of the current battle over deconstruction [FN1] is whether resort to legislative intent might help to determine the content of a statutory text that otherwise, in splendid isolation, could be deconstructed by simply positing different interpretive contexts. Thus, a doctrinalist might argue that one can obtain a degree of certainty of meaning of any legal text by referring beyond the text itself to the intention of its author.[FN2] Because no interpreter has direct knowledge of the mind of the author, the author's "intention" seems to constitute another text-a point of reference separate from and in addition to the primary text that is the subject of interpretation. The question is whether we can use this other text - this "evidence" of authorial intent - to pin down the meaning of a statute. Professor Michael Moore is among those who would have liked to use "intention" as a possible way to find determinate meaning in a statute, but after thorough consideration he reluctantly concluded that the meaning of a [pg562] statute cannot be ascertained by recourse to legislative intent.[FN3] His approach was entirely formal.[FN4] In this Article I examine the same issue by recounting my own quest for determinate meaning in statutes - a sort of personal legislative history. My conclusion will deviate slightly from Moore's, as I believe that a legislature can use its audience's own theories of interpretation to influence probabilities of how its statutes are likely to be interpreted.[FN5]

Statutes are certainly the dominant form of law in our times. The theory of positivism tells us that law is a command - one that emanates for the most part from legislatures, but sometimes from prior judicial decisions.[FN6] Accordingly, much of current legal scholarship has been devoted to the question of legislative and constitutional interpretation. [FN7] My starting point, however-in alignment with Stanley Fish [FN8] — is that there can never be a definitive theory or set of rules of interpretation.

Here is a simple proof of that proposition. We begin by assuming that which we are trying to disprove: namely, that there is a theory of interpretation-some set of rules or formulae, an essay, a book, several volumes of books, or all the books one reads in three years of law school-that we can consult in order to learn how to interpret any legislative enactment. [FN9] Then we ask: What are the rules for interpreting this assumed theory of interpretation? Must we look to the biographies of the scholars who came up with these rules or formulae or books to resolve questions concerning what they mean in specific [pg563] cases? Or is it impermissible to look to their biographies? Should we interpret their words according to definitions in Black's Law Dictionary or any other legal source? These questions suggest that we need a meta-theory of interpretation to enable us to interpret the rules or formulae or books of interpretation. But such a meta-theory would constitute a text, and thus itself be in need of interpretation. It would require a meta-meta-theory of interpreta- 
tion in order to be interpreted. We thus proceed into infinite regress. Because we cannot consult an infinite number of theories in a finite amount of time, we must conclude that any general theory of interpretation is impossible.

Nevertheless, statutes are "interpreted" all the time, and those who do the interpretation typically think that they are following certain explicit or implicit rules. Of course no one can deny that many judges, lawyers, and scholars say that they "interpret" statutes according to time-honored rules and principles of interpretation; the question is whether their activities are actually constrained by any such rules or principles.[FN10] Deconstructionists, following Professor Fish, claim that any rules of interpretation judges and lawyers say or think that they are following are in fact the product of the way they have chosen to interpret the statute. Their actual mental procedure is as follows: (1) read the statute; (2) notice that your reading of the statute seems best to fit one of a large number of "rules of statutory interpretation" that you are acquainted with; (3) tell your audience that in interpreting the statute you followed that rule. I do not claim that this rationalization is disingenuous; rather, it seems to be the way the mind works with respect to all theory, not just theories of interpretation. [FN11]

[pg564] Yet I think there is something to be said for the idea that our state of mind when we look at a statute — a state of mind that may partially be described by "rules of interpretation"—may at least somewhat influence what we think the statute means. Einstein remarked that everything we see reflects what we think we are seeing.[FN12] Surely our understanding of every statute we read reflects what we think we are reading. Hence whatever theories fill our minds partially form the context within which we read texts. My thesis in this Article is that the anticipated mental context of addressees partially shapes the strategy of legislators in formulating statutes. Because legislators know that the addressees of their statutes will interpret those statutes according to whatever contexts and theories the addressees have in mind, and know further that the addressees will (probably) not be able to break through those contexts to choose among a much larger set of possible interpretations, rational legislatures will take the anticipated mind-sets of addressees into account in choosing how to write statutes. This is at least the thesis I want to expound here, and although it may seem to run counter to some of Fish's arguments, it accepts his main conclusion: there is no such thing as a prescription for interpretation.

Accordingly, I shall look at "interpretation" in a light that departs from mainstream interpretive scholarship. I will argue that interpretation is a stage in the process of communication between the legislature that enacts a statute and the members of the judiciary (or practicing bar or the public) who are the addressees of the statute. I shall argue that the legislature, in order more effectively to communicate its command, initially wants to know something about the mind-set of the addressee. The legislature, after all, does not want to launch its statutes into the void; rather, it has in mind a certain class of addressees, who might typically be expected to react in various ways to the legislative message. The expected reaction of the addressees [pg565] thus becomes a factor in the legislature's output. [FN13] It is in the legislature's interest to reduce, if possible, the degrees of freedom that attend the addressee's interpretive processes.

\section{Communication Is Constrained By the Receiver's Mind-SeT}

Any person, such as a legislator, who issues an order is engaged in a process of communication. The enactment will only be effective, from the legislator's point of view, if it is interpreted with rea- 
sonable accuracy. Because each person (judges, attorneys, the public) who reads or hears the legislative message necessarily interprets it, the legislator may conclude that the more she knows about the interpretive processes of her audience, the more she can tailor the words of the statute so that the audience will interpret it the way she wants it to be interpreted.

The clearest illustration is a coded message. If military headquarters wants to send a message in code to its officers in the field, it must have previously communicated with those officers in order to inform them how to decipher the code. The communication could take the form of training, of handing over a decoding book, or of handing over a programmed computer (a cipher) that will do the decoding. The very idea of a secret code presupposes at least one communication between sender and receiver other than the code message itself.[FN14] That one communication conveys the decoding instructions - the "key" to the code. The communication of the key is necessary to prepare the addressee to decode the message.

[pg566] It is necessary, but not sufficient. Suppose a code-"78987452112361"—is received and decoded (interpreted) as "attack at 0700 hours." The decoded message can still be ambiguous. For example, does "attack at 7 a.m." mean the time the bombers should cross the enemy's borders or the time that the bombs should be dropped? The message is ambiguous between at least two possibilities of when the "attack" should take place. If the officer who receives the coded message has been kept in the dark about what other units are doing, he may have no way to resolve the ambiguity. Any reader of the detailed military histories of World War II knows that there were countless instances of misinterpreted messages resulting in enormous casualties.[FN15] As the war went on, the rate of misinterpretations declined as senders and receivers became accustomed to the varied contexts in which messages had to be interpreted.[FN16] Even so, such breakdowns occurred even between trained senders and receivers working within codes designed to convey precise messages about a relatively narrow subject-matter.

Thus in sending a coded message, it is insufficient merely to have someone on the receiving end who can decode it; the sender also has to know something about the receiver's tendencies in interpreting messages. But even if a great deal is known about the receiver's processes of interpretation, the message can still be ambiguous simply because the sender does not know the factual context in which the [pg567] receiver receives the message. The ambiguity increases if the sender is increasingly unsure about who the receiver is. Perhaps the most extreme cases are attempts at extraterrestrial communication [FN17] such as those included on the Pioneer 10 and Pioneer 11 space probes launched by the United States in 1972 and 1973. Affixed to these probes were six-inch by nineinch plaques of gold-anodized aluminum with a message to our hypothetical neighbors in the Milky Way Galaxy. Pains were taken to communicate a peaceful attitude as well as basic information such as our location within the galaxy in a manner that could be deciphered by extraterrestrials. A drawing of human beings also was included. [FN18] Although many have speculated as to how any possible extraterrestrials might interpret the message, let us suppose that we receive a "return" message from outer space in apparently plain English. [FN19] How could we possibly "interpret" it? No matter how "familiar" the words, we could have no idea that the words mean the same thing to the sender as they do to us. [FN20] A related problem is that the distant galaxy might be trying to fool us. Having beamed in on our radio and television transmissions [FN21] after being [pg568] alerted to our presence by the Pioneer probes, they could have figured out what we wanted to hear while disguising their true purpose-which could be simply to scout us in order to decide whether we appear to be tasty enough to justify their coming all the way here for a good meal.[FN22] 
In general, it appears to be impossible to interpret any text without ascribing desires, beliefs [FN23] or purposes to its author. The very ascription of some set of desires, beliefs or purposes enables us to give what we call "meaning" to the text. Obviously, if we have no idea at all whether the attributes that we ascribe to the text-writer are true-for example, when we think a text is written by a non-human from another galaxy-we can be making a disastrous error in our "interpretation" of the text.

Even if the sender knows something about the personality and mind-set of the receiver, the possibility of radical misinterpretation can never be reduced to zero. Literature is full of examples of misinterpreted messages from master to servant. French farces excel in misinterpreted communications: humor seems maximized the more a "literal" interpretation is grotesquely inappropriate in the circumstances. More [pg569] recently, we have become familiar with the single-minded literalness of computers. Norbert Wiener observed in God and Golem, Inc.:

If you are playing a game according to certain rules and set the playing-machine to play for victory, you will get victory if you get anything at all, and the machine will not pay the slightest attention to any consideration except victory according to the rules. If you are playing a war game with a certain conventional interpretation of victory, victory will be the goal at any cost, even that of the extermination of your own side, unless this condition of survival is explicitly contained in the definition of victory according to which you program the machine. [FN24]

Wittgenstein noted in his Philosophical Investigations, "Someone says to me: 'Shew the children a game.' I teach them gaming with dice, and the other says 'I didn't mean that sort of game."' [FN25] And Lon Fuller adds in "The Case of the Speluncean Explorers":

The stupidest housemaid knows that when she is told "to peel the soup and skim the potatoes" her mistress does not mean what she says. She also knows that when her master tells her to "drop everything and come running" he has overlooked the possibility that she is at the moment in the act of rescuing the baby from the rain barrel. [FN26]

But why exactly did the master say "drop everything and come running" instead of "please come here?" We have to fill in the context prior to the master's statement. Imagine previous communications between master and housemaid, where the latter interpreted "please come here" as meaning "whenever you're finished what you're doing, come here." [FN27] In order not to leave wholly up to the housemaid the judgment of when to come, the master has jumped to the opposite extreme and orders her to "drop everything and come running." He might even have added, "And I really mean it!" But training her in literalness can have its price. If contrary to Professor Fuller's guess [pg570] the housemaid drops the baby into the rain barrel and explains later to her employer, "Well, you told me to drop everything!" she would be showing him the folly of teaching her a theory of literal interpretation.

The master-housemaid interaction could go back and forth without ever being resolved, ending either in tragedy or in a French farce. Why in real life don't these misinterpretations continue unabated? I venture to suggest that the sender of the messages learns over time how particular receivers of the messages tend to interpret them, and adjusts for those interpretations. Error can never be completely avoided (because messages that seem unambiguous can turn out to be ambiguous if the receiver is in a factual context unknown to the sender [FN28], but the familiarity that obtains over time probably reduces error enough that life and communication can go on. The master is upset when the experienced housemaid leaves her job, because that means he must endure another series of mistakes and misunderstandings while a new housemaid learns by trial and error what he probably intends. [FN29] 


\section{Can the Message Prepare Its Audience?}

In messages other than codes, where the receiver is indeterminate (as in all public legislation), is there any way to communicate the desired interpretation along with the message? [FN30] Consider the marvelous [pg571] opening paragraph of Vladimir Nabokov's novel, King, Queen, Knave:

The huge black clock hand is still at rest but is on the point of making its once-a-minute gesture; that resilient jolt will set a whole world in motion. The clock face will slowly turn away, full of despair, contempt, and boredom, as one by one the iron pillars will start walking past, bearing away the vault of the station like bland atlantes; the platform will begin to move past, carrying off on an unknown journey cigarette butts, used tickets, flecks of sunlight and spittle; a luggage handcart will glide by, its wheels motionless; it will be followed by a news stall hung with seductive magazine covers - photographs of naked, pearl-gray beauties; and people, people, people on the moving platform, themselves moving their feet, yet standing still, striding forward, yet retreating as in an agonizing dream full of incredible effort, nausea, a cottony weakness in one's calves, will surge back, almost falling supine. [FN31]

Obviously, a novel will be picked up by an enormously diverse group of potential readers. Some will read this first paragraph and say, "Another artsy incomprehensible book—not for me." Some might say, "Ridiculous - the author must be on a different planet." But others, whom Nabokov was probably trying to reach, may interpret the passage as indicating something more or less like the following:

We have a passenger seated on a train looking out the window and waiting for the train to start, and when the minute hand of the big station clock makes its one-minute jump to the departure time, the train starts, and then the passenger - experiencing perhaps existential despair or regret of leaving the familiar world of the train station — views that world as if it is moving away from him while the train stands still, and sees his world of platform and station jolting into backward motion and being carried away from him piece by piece, while the people on the train platform react sluggishly (because they are moving in the same direction as the train, only more slowly) as in a dream that will inevitably take them backward into the void.

The reader then reflects upon why the book began this way:

By reporting literally what he saw, the passenger in effect was conveying something of his thoughts and feelings to me. Nabokov, the [pg572] author, was able to let me see the train station from the passenger's point of view, recreating in my mind the emotions the passenger felt. If I imagine myself sitting in a train and seeing exactly what the passenger sees, then I too begin to feel in the pit of my stomach his reluctance at leaving his world of the station behind, because I've felt similar things in the past in looking through the windows of trains. I can internalize the disorienting feeling of seeing crazy passengers moving their feet but only standing still and then starting to lose ground. By telling me what I am "seeing," Nabokov has recreated in me the fictional passenger's emotions in leaving the train station!

But I also know that what I am "seeing" through the eyes of this passenger is a gross misinterpretation of reality. The people on the platform are not moving their feet while lurching backward as the platform recedes underneath them into the void. They are actually walking in the direction of the train, and it is the train that is moving, not the platform.

Curious how at one and the same time I internalize the emotions of the passenger and yet distance myself from his interpretation of reality. Maybe Nabokov wanted me to locate my feelings somewhere in the netherworld between the existential despair of the passenger and the cold reality of the normal way I should perceive a train station through the window of a moving train.

Clearly the foregoing interpretation assumes a normal and reasonable reader-one whose thought processes are familiar to us. Suppose instead we have a very strange reader-a reader from the galaxy Antipodes. Assume her home planet resembles ours, except that everyone there including herself routinely believes that vehicles do not move but rather that the land beneath the wheels 
moves backwards. If she read the text, it would seem to her like a perfectly proper reporting of events. All Nabokov's careful work would be wasted on her. Yet isn't her interpretation as valid as ours? [FN32]

In one sense, the Antipodean has simply excluded herself from the category of people who would be interested in Nabokov's novel. She is like the reader who found it to be too "artsy," except that in her case she thinks it is not artistic enough. Nabokov presumably was not writing the book for either of these types of reader.

[pg573] But this is not to say that the paragraph cannot be reformulated for an Antipodean audience. If Nabokov had lived on that planet, he presumably would have started his book from the point of view of a passenger seated on a train who believes that the train is moving and the station is standing still. That might strike his audience as very interesting. The situation would recall the British witticism, "Does Oxford stop at this train?" The Antipodeans presumably would fail to see any humor in that remark. They might, however, laugh if someone asked, "Does this train stop at Oxford?" [FN33]

Suppose you are a bookseller trying to sell the actual Nabokov novel (that is, the earth-version) to the Antipodeans. You could explain to them that the passenger on the train in the Nabokov novel is deliberately misinterpreting reality. Yet the Antipodeans might think you are crazy - the Nabokov text to them exactly describes mundane reality. [FN34] Can we appeal to Einstein's theory of relativity in explaining our interpretation of reality to the Antipodeans?

In a 1918 dialogue — which could have inspired Nabokov's opening paragraph [FN35]—Einstein contrasts relativity with "common sense":

The uniformly traveling train could just as well be regarded as "at rest," and the rails along with the entire region as "moving uniformly." Will the "common sense" of the locomotive engineer admit this? He will object that it is after all not the region which he has to continually heat and grease, but the locomotive, and that consequently it must be the latter in whose motion the effect of his work may be seen.[FN36]

[pg574] But Einstein goes on to show that this "common sense" view is merely convenient, and not necessary in principle. He asks us to imagine the earth as falling freely in a gravitational field, while the train is prevented from falling freely by the friction exerted by its wheels against the track. [FN37] Specifically, we can imagine that Nabokov's station is indeed moving away from the passenger in the train, and that the train would move along with the station but for the braking action of the train's wheels, whose rotational motion restrains the train from falling backwards at the same speed as the rest of the station. In Einstein's view, this is exactly equivalent to regarding the train as moving. The engineer heats and greases the locomotive to increase the friction between locomotive and track, thus increasing the speed at which the station falls away from the train. Presumably, Einstein would not regard the Antipodeans in my imaginary example as having a strange view of reality, but rather would recognize their view as fully equivalent in every physical respect to our own.

If we were to internalize fully Einstein's theory of relativity, so that we would routinely view the motion of trains as, interchangeably and alternatively, either the motion of trains or the motion of stations, then Nabokov's image would lose much of its effect upon us. The artistic force of Nabokov's image depends upon the fact that we normally and usually do not interpret what we see through a train's window as the station starting to move backward. Professor Fish might say that our experience in reading Nabokov's text depends upon the interpretive community in which we 
happen to be immersed-which, [pg575] at present, is one in which we do not carry around in our heads either the Antipodean interpretation of motion or the Einsteinian equivalence interpretation.

But what is this claim other than that a good author makes a calculated guess as to the interpretive community of the future readership of his novel and writes accordingly? One can hardly doubt that Nabokov started his novel with the paragraph quoted above because he consciously or subconsciously counted on the fact that most of his readers belong to a conventional interpretive community and not an Antipodean or Einsteinian one. And if they were to become Einsteinians in the distant future, he may well have calculated that by then he would not be around to lament the decline in royalties.

Unlike the sending of a coded message, where the sender must previously have alerted the receiver to the code, I am claiming that Nabokov's opening paragraph itself assumes the existence of a decoder in the minds of his readers. The code is the common view that earthlings (nonAntipodeans) who are nonphysicists (non-Einsteinians) carry around in their heads-a code which says that trains move and stations stand still. Because some possible readers (Einsteinians, Antipodeans) do not have that mental code, we can guess that the author would not go over well with such readers - that indeed they would be unable to decipher his message. In military terms, they would simply lack a decoding device.

Another way of saying that the opening paragraph contains a coded message is to say that it is theory-dependent. Nabokov apparently counted on a theory of interpretation-one inside the reader's mind - that enabled him to produce an artistic effect in the reader by the literalness of the passenger's description of the scene through the train window. If some readers (Antipodeans or Einsteinians for example) do not adhere to that theory, then the force of the opening paragraph will largely be lost on them.

\section{THE PROBLEM OF INFERRING INTENT}

The foregoing, however, seems distinctly anti-Fishian. If I were postulating some kind of intentional strategy on the part of the author Nabokov purely on the basis of the text that he has written, Fish would surely object that I cannot possibly discern the author's intent from the text alone. In a standard example, how can we possibly know anything at all about the original intent of the framers of the [pg576] Constitution from reading the text of the Constitution, or any other texts for that matter-including texts containing all recorded deliberations and contemporary writings of the framers?

Let me first clear away one nonstarter in the question just raised. No one can ever know with certainty what any author's intention or strategy was. [FN38] Indeed, Marvin Minsky (an authority on artificial intelligence) might say that even the author cannot know.[FN39] In the Nabokov example, I was only invoking probabilities. It is more probable than not that Nabokov [FN40] wrote for an interpretive community that typically viewed trains as moving and stations as standing still. [FN41] In everything that follows, I also make probabilistic and not certainty statements. [FN42] Thus, putting this point aside, I can join issue with Professor Fish on more realistic turf.

[pg577] The question, then, is whether in some cases we can posit theory-dependency on the part of the message-sender (such as the legislature in sending a statute out into the world). Perhaps the most efficient way I can deal with this issue is to recount some events that helped unfold the issue for me. 
Vladimir Nabokov was in his penultimate year of teaching at Cornell [FN43] when I had the good fortune to enroll in his class in modern literature. A short story of Kafka's struck me as an allegory about Christ, and so I asked Professor Nabokov after class whether it was supposed to be an allegory about Christ.

"No, No!" he answered in his gentle basso tones. "That's the wrong question! You don't ask what the text is supposed to be! The text is not supposed to be anything - other than a text, of course. You should ask instead what the text means."

"But if I ask you what it means," I replied, "you'll say that it means whatever the author intended it to mean."

"Precisely right."

"All right, Mr. Nabokov," I said, "did Kafka intend it to be an allegory?"

"Aha," Nabokov replied, "now that you've correctly stated the question, your answer will be found in the text. Go back to the text and re-read it!"

This conversation encapsulated a duality that seemed to flow through Nabokov's entire course. On the one hand, he insisted that the "good reader" (that is, the sort of reader he wanted his students to become) reads a work of literature as a conversation between author and reader. [FN44] Hence, all that counts in interpreting a book is the intention of the author, conveyed through the conversation between author and reader. On the other hand, Nabokov insisted that nothing outside the four corners of the book could conceivably be relevant to [pg578] the task of determining the author's intention. Even a definitive biography[FN45] of the author could be more misleading than informative about what the author intended. If we discovered, for example, that Flaubert patterned Madame Bovary after a woman of his acquaintance, any knowledge that we could gather about that real woman would just as likely as not mislead us in our interpretation of Madame Bovary. [FN46] The real world, including the real world of the author, cannot tell us how to resolve ambiguities in the text or pour meaning into any words or images that the author conjures up. The author is, after all, engaging in a process of artifice. The author is writing fiction.[FN47]

But if we are to determine the intent of the author by reading a text and yet are precluded from looking anywhere other than the text to discern that intent, why talk about the intent of the author at all?[FN48] Why doesn't Nabokov's position reduce simply to saying that the text [pg579] itself determines how we are to interpret it-a position that would appear to be the exact antithesis of Fish's?

I received a possible answer to that question in a conversation I had with Professor Ernest Brown in law school two years later. I did not have the good fortune to take his course. (In those days students had very little choice in course selection and none in choosing professors.) I was writing a note on the taxation of collapsible corporations and caught up with Professor Brown in the hallways between classes. As we walked together I asked him what materials I should consult to interpret the intent of Congress in writing the section of the Internal Revenue Code on collapsible corporations.

Professor Brown's answer, at first, was very Nabokovian: "The best evidence of Congress's intent is what they said in the particular statute you're construing."

"Yes, Ernie, I know," I replied, "but the words of the statute don't seem to add up to any coherent account that I can put together about the intent of Congress." 
"But what you're missing," he said, "is the fact that Congress intended to levy the tax according to the words of the statute."

Professor Brown's remark (as had Nabokov's) sent me back to the drawing board for days of furious thought. The Brownian position was worlds apart from the Nabokovian position, even though superficially they seemed to be similar. Nabokov would never have said that Kafka's intention was nothing other than the words he wrote. Kafka, according to Nabokov (as I interpreted Nabokov), did not write books of words; he wrote books that had meaning expressed in words. [FN49] But then, I thought, maybe the difference between Nabokov [pg580] and Brown is the difference between literature and law. [FN50] The law, after all, is a very practical affair; literature, in contrast, is otherworldly. Nabokov always said that literature is artifice, and that the world of the novel is a probable world somewhat askew of the real world that we know. [FN51] On the other hand, in the real world of law and legislation, there are real legislators who have real meanings that they want to pour into nonfictional statutes. With Professor Brown I was back on solid ground, construing a highly real (and from a literary standpoint intolerably boring) section of the Internal Revenue Code.

Then a third professor entered the picture who turned out to have the decisive influence on my decision to teach law. Lon Fuller's jurisprudence made it impossible for me to draw a facile distinction between literature and law and thus to avoid the problem caused by the apparent conflict between Nabokov and Brown. For Fuller's view [pg581] of textual interpretation of statutes turned out to be very close to Nabokov's, even though Fuller was dealing with legal texts. According to Fuller, statutes are enacted by legislatures in order to manage the affairs of society with some degree of general rationality. When we read a statute, we have to interpret it in light of this assumed reasonable purpose. [FN52] Fuller's best example, I think, is in his "Case of the Speluncean Explorers." There he imagines a statute with the word "not" inserted in a place that renders meaningless the purpose of the statute:

[I]n Fehler v. Neegas there was before this Court for construction a statute in which the word "not" had plainly been transposed from its intended position in the final and most crucial section of the act. This transposition was contained in all the successive drafts of the act, where it was apparently overlooked by the draftsmen and sponsors of the legislation. No one was able to prove how the error came about, yet it was apparent that, taking account of the contents of the statute as a whole, an error had been made, since a literal reading of the final clause rendered it inconsistent with everything that had gone before and with the object of the enactment as stated in its preamble. This Court refused to accept a literal interpretation of the statute, and in effect rectified its language by reading the word "not" into the place where it was evidently intended to go. [FN53]

If we choose to ignore the word "not"-no matter how persuasive the reason we can adduce for our choice-we must concede that we cannot interpret the intent of Congress solely according to the words Congress used.

So Fuller and Nabokov disagreed sharply with Brown. Then what was Brown telling me? He could not have been unaware of the Nabokov-Fuller view. I concluded that Brown was carrying that view a logical step further in his conversation with me about taxation. What in essence he must have been saying to me is as follows: Congress [pg582] has become frustrated in watching the courts second-guess the tax statutes. No matter what Congress intended, the courts were able to find some intent or purpose in the statutes that, in particular cases, led to results at variance with what Congress intended. The problem for Congress then was to ensure that its own intent would be given effect, and not some judicially presumed - but false-intent. [FN54] The strategy Congress came up with, at least in the tax area, was to say-as Brown interpreted Congress to say — that its intention was to levy the tax according to the words of the statute. Thus, the courts should simply 
apply the words, whatever they are. If the word "not" is in the statute and it looks absurd, apply it anyway. (This is like saying "drop everything and come running — and I really mean it!") At least, according to Brown, in Congress's considered judgment more cases will more likely be decided according to Congress's real intent if the courts simply "apply" the words than if the courts try to figure out what intent Congress really had. Congress, in brief, made a cost-effective calculation: better to have the courts apply the words, no matter where the words might lead, than to have the courts second-guess Congress by resorting to some sort of mystical intent-divination. [FN55]

Now, maybe this account of what Congress really intended is correct. Maybe Brown was not, as it first appeared, giving me a principle of statutory interpretation ("The intent is to legislate according to the words"), but rather opening up for me a way of dealing with tax codes. The way to deal with a tax code is a matter of rhetoric: to argue to a court (or in a law journal) that there is no independent reality to a collapsible corporation, but rather than if a given set of paper transactions corresponds to the words Congress used in defining and taxing what Congress defined as a collapsible corporation, then for tax purposes that set of paper transactions amounts to a collapsible corporation. And if one needs more to accompany this highly positivistic account of what is going on in the collapsible corporations [pg583] section of the tax code, one simply tells the story about the continuing battle between Congress and the courts over the intent of Congress and Congress's determination to end the fight by instructing the courts that it forevermore intends to levy the tax according to the words of the statute.

Why only tax codes? Because it may not be so important whether absurd taxes are levied. Congress can always pass a private bill to reimburse a taxpayer who was the victim of a statute that wrongly contained the word "not," and Congress can always amend the statute and take the word "not" out. Furthermore, tax distinctions are often themselves intrinsically arbitrary, the result of legislative compromises that have little to do with the real word (e.g., the real world does not tell us how to spot a difference between regular income and capital gains). As a result, a court might be unable to determine whether the word "not" was purposefully or inadvertently omitted from the statute. Even legislators, if polled, might disagree sharply on this issue. The net result of these considerations is that Brown's literal approach may be the most cost-effective in the area of taxation: if some people are unfairly taxed no great harm is done-it is not like losing the baby in the well. But in other legislation, such as criminal law, the positivist-literalist interpretation of intent could lead to real and sometimes irreversible human losses, and therefore those statutes might have to be read as Nabokov and Fuller would read them.

For a while, I was content with the dichotomy between tax legislation ("tax according to the words") and other legislation ("apply according to the meaning"). But it soon dawned on me that this was no better than the other dichotomy that I had lived with for a while but eventually discarded - that between law and literature. Why should there be a fundamental difference between kinds of legislation, such as between a complex tax code and a simpler criminal code? And if there is no such difference, must I use Brown's approach in interpreting all the areas of law, including criminal law? Everything I knew about law-especially the commonsense things I had not quite discarded even in law school—counseled against such an approach. Following such an approach could entail sending someone to jail because the word "not" was mistakenly included in the statute. I knew that literal readings and the whole formalist approach to the law were one of the biggest problems about law. The legal system perpetuates a great deal of injustice by adhering to formalism and literalism [pg584] and insisting upon what are pejoratively called "lawyers' technicalities." There was no choice for me but to go in the opposite direction—against Brown. I could not say that 
formalism is all right for tax codes but not for other areas of law. Rather, I would have to arguealthough it was the much harder argument to make- that even tax codes cannot be interpreted according to the words. [FN56]

The conclusion I now felt I had to defend was that Brown's theory was unworkable even for tax codes. His theory must be shown to fail to achieve the purpose that Congress had in mind in the cautionary tale of the battle of interpretation between Congress and the courts. At the very most it gives us what Fish tells us is all that theories of interpretation can give us - a plausible rhetoric. [FN57] Thus my conclusion. But what support could I give it?

Support cannot be found if we look solely to tax codes or cases that construe tax codes. The evidence we must look to is tax avoidance. That evidence is not readily available in law books, because the better the tax-avoidance lawyer, the less likely the scheme will be contested by the government. Yet I did discover over the years that what actually happens as a consequence of adhering to Brown's view is that the tax planners will figure out ways to structure paper transactionsincluding the invention of corporations and other entities solely for tax avoidance - that literally step by step escape every trap-word in a statutory provision and thereby avoid being captured by the statute. [FN58]

But that strategy inevitably generates the form-substance problem. All tax planners will comply exactly with the form of the statute so as [pg585] to avoid falling within any category to which the higher tax applies. [FN59] No matter how ingenious or how detailed Congress might be in writing the statute, and no matter how often the statute is revised to plug loopholes, [FN60] tax planners enjoy enough degrees of freedom to comply exactly with Congress's formal structure and yet avoid paying the higher tax (or in some cases, avoid paying any tax at all).[FN61] In an earlier article I contended that legal rules in general (including, of course, tax codes), to the extent that they are construed as literal commands or propositions, obey a kind of second law of thermodynamics-they deteriorate with age in the sense that they become increasingly uncertain in meaning and increasingly unable to guide [pg586] conduct as they were intended to do.[FN62]

Of course, with every action there is a reaction. To the extent that Brown's literalist theory of tax interpretation is followed and wealthy individuals become increasingly able to avoid paying tax, sooner or later the courts must depart from the literalist theory. And so they did, starting with Gregory v. Helvering in 1935[FN63] and continuing with inevitably increasing frequency down to the present, by inventing and applying the "business purpose rule," which is not itself in the tax code. They hold that paper transactions that comply with the letter of the tax code but lack an independent business purpose shall not be given a tax-avoidance effect. [FN64] No matter how exact the correlation between the words of the statute and what the taxpayer does, the intent of Congress could not possibly have been - according to the courts - to let the taxpayer avoid paying the tax merely because the taxpayer was ingenious enough to comply exactly with the words of the statute. Hence Brown's theory is refuted, and we are back to Nabokov and Fuller-and to an extent Fish. No set of words can in themselves do the "law job," and no number of amendments or explanatory paragraphs or loophole-plugging or preamble-writing can save the situation, because all of the latter are simply examples of more words chasing the original words. (And, to boot, the "business purpose" theory cannot do the job, either, [FN65] nor can the practice of [pg587] "recharacterizations" by the Commissioner of Internal Revenue. [FN66])

The foregoing is not to say that Brown was wrong. On the contrary, he may very well have given me the best available theory of what Congress intended in writing the tax codes, or as Fish 
might say, the best current way of "presenting" what Congress "intended." [FN67] But his theory must and does fail in the highly ramified area of taxation, and hence should fail in all other areas of legislation as well. [FN68] Yet the failures are always and only failures of our own expectation. We never should have expected that a legislature could force a single interpretation of its commands upon any addressee. If we change our expectation - if instead we hope for a reduction in the degrees of freedom the addressee believes are available to him in interpreting a statute-we may make a little progress.

\section{RADICAL INTERPRETATION}

The examples I used in the previous section share the feature of presenting radical challenges to what we might call the ordinary, reasonable, expected interpretation of statutes. Curiously, radically strange interpretations of any message may be more difficult to guard against than interpretations that only vary slightly from the expected interpretation. (And certainly, as Professor Kelman observes, the extreme and excessive cases have "critical" rhetorical power. [FN69] These are the cases that tend to show up in law-school class discussions and [pg588] in law review articles.[FN70])

Consider some of Dworkin's bedrock examples of texts that he claims cannot possibly be misinterpreted except if someone is deliberately perverse. Stating the precise opposite of the position I've taken in the preceding paragraph, Dworkin writes in Law's Empire:

\footnotetext{
You and I can sensibly discuss how many books I have on my shelf, for example, only if we both agree, at least roughly, about what a book is. We can disagree over the borderline cases. I may call something a slim book that you would call a pamphlet. But we cannot disagree over what I called pivotal cases. If you do not count my copy of Moby-Dick as a book because in your view novels are not books, any disagreement is bound to be senseless. [FN71]
}

Yet here are some ways, not all of which are necessarily perverse, in which I can refuse to count Dworkin's copy of Moby-Dick as a book-ways that are quite unlike the somewhat simpleminded position ("novels are not books") that he puts in the mouth of the reader:

1. Dworkin has simply solved one problem by creating a similar problem of equal difficulty. He presupposes that "we both agree, at least roughly, about what a book is." But what does he mean by "roughly"? Dworkin simply shifts his question about "books" to an identical question about "roughly."

2. Moreover, Dworkin begs the question he asks. If we agree about what a book is, then his conclusion follows that we agree-but it is an empty tautology.

3. Perhaps Dworkin feels we can disagree about what it means to count as a book. But then we are faced with innumerable and conflicting methods of "counting." For example, Dworkin might say there are five books on his shelf and I might say there are 101. If he is using numerals in the decimal system and I am using numerals in the binary system, we can be referring to the same items on the shelf.

4. Suppose Dworkin says there are five books on his shelf and I say there are forty-three. He points to the items on his shelf and asks me if there are any that I "see" there that he doesn't see, and I say no. He asks me if I am using numbers to any base other than the decimal [pg589] base, and I say no. Then he asks me how I counted forty-three books. I pick up one of the books on his shelf, 
which is the Old Testament, and show him that it contains thirty-nine books. That plus the other books on his shelf adds up to forty-three.

5. The term "book" is subject to an unspecifiable number of interpretations. [FN72]

6. Dworkin's copy of Moby-Dick, for all we know, might be an audio tape.

7. It might be a file on his computer's hard drive.

8. It might be the "classic comic" version of Moby-Dick.

9. Why should I assume that Dworkin's copy of Moby-Dick is a copy of a book with that title? Maybe it is only a copy of the title "Moby-Dick." Thus his "copy" of "Moby-Dick" might be two hyphenated words that are printed on a piece of paper (the words "Moby-Dick").

10. I could argue that, if a novel is a book, then Moby-Dick isn't a novel. (Moby-Dick is a morality play, with many dialogue scenes, lengthy stage directions, and background information in the form of newspaper clippings and assorted commentary.)

Recently in a discussion of this same topic a law professor picked up a book, held it in his hands, and asked me whether I could call what he was holding a "globe." I replied, "Yes, if this were an audience of mathematicians, or if you're willing to go along with math-talk. What you're holding is the topological equivalent of a sphere or globe." [FN73]

Or consider Dworkin's claim that no one who regards Hamlet as a forceful man of action could possibly have interpreted the play correctly. [FN74] Stanley Fish replies:

[pg590] The reason that the example of Hamlet as a forceful-man-of-action seems such a good one to Dworkin is that Hamlet's indecisiveness has been part of the interpretive tradition for so long that it is almost proverbial. ... [I]t is not impossible (although neither is it inevitable) that there could come a time when because of an argument successfully prosecuted-perhaps one in which Hamlet is from the very first executing a predetermined plan - the hero of Shakespeare's play will be regarded as the very type of decisiveness. [FN75]

Even in the present interpretive climate I think one could argue, contrary to Dworkin, that Hamlet was only portraying what it would be like to be indecisive. My argument quickly sketched is as follows: Hamlet is really a play about a play. The lead actor is presenting a masterly performance of acting the role of a prince in Denmark, a prince given to highly theatrical declamations that run the thespian gamut between sanity and madness, between reality and ghosts, between ontological philosophy and mundane existence. The lurid and overblown drama of Shakespeare's lines suggests that we are not to take them as a depiction of something that happened in Denmark but rather as an extended audition of acting ability in a Danish setting. There is even a tip-off that Hamlet is a play about a play: the "play within a play" of Act III, Scene 2-a wholly overblown quasi-dramatic rendering of the murder of Duke Gonzago, preceded by Hamlet's instructions to the players about the art of acting. [FN76] In brief, my argument is that Hamlet is a play about acting in a play.

Indeed, a totally radical interpretive theory can be built upon this one. Were Dworkin further to contend in accordance with received wisdom that Hamlet is a tragedy, I might attempt to defend as follows the proposition — which as far as I know has never been asserted - that it is a high comedy. I contend that the play about a play that I have just described — that is, the "play" that we see on the stage - is a [pg591] comedy; it's only the play that is being auditioned that is a tragedy. We are seeing a comedy about actors acting out a tragedy. [FN77] Shakespeare may have been three centuries ahead of his time as a humorist; only recently have we been seeing the kind of black humor (from Steve Martin, and before him from Lenny Bruce) that Hamlet typifies. [FN78] Imagine: a colossal 
joke is being played in a theater; the joke is that the audience at first thinks it is seeing a very "heavy" tragedy; but only when it recognizes that it is "too much," that the lines are written in "black letter" so to speak, that the "tragedy" is being performed as a tour-de-force by the actor who plays Hamlet, does the vast scope of Shakespeare's humorous conceit become comprehensible. Moreover, there was method in Shakespeare's comic madness-only such a unique play about a play can demand acting ability that can truly be called consummate, for the actors must simultaneously be believable within the play that they are playing, while also (with straight faces) be believable as actors dressed up in courtly raiment [pg592] declaiming the ponderously immortal lines of that play within a play. [FN79] Although I've never seen Hamlet presented this way, I can imagine - or fantasize - that it may have been performed as a high comedy to laughing audiences at the Globe Theater during Shakespeare's time-to audiences that were far more "knowing" about Shakespeare's actual "intent" than theatergoers have been since then.

Whether or not my reinterpretation of Hamlet is off-the-wall, my point has been to proveusing Dworkin's own examples - that radical reinterpretations are always possible. [FN80] Even as lengthy a play as Hamlet can be interpreted either as a tragedy or as a comedy. Minor variations in interpretation-consider ten actors playing Hamlet in ten productions, all of them with varying degrees of skill in portraying an indecisive prince of Denmark-are more easily compared and rated against one another. A theater critic can say that the third actor was better than the fifth, but only because she has a mind-set that accepts a minor range of variability in interpreting a set vision of the play-a vision of an indecisive prince. Critical "disagreement" over the borderline cases is weak tea. We may disagree, we may argue, we may debate, but only because we are standing close to each other on common ground. This is not the profound kind of disagreement I imagine you had with me when I tried to argue in the previous paragraph that Hamlet is really a comedy.

I have also tried to show, by these examples, that if the audience already has a certain mind-set, the meaning of the message is less susceptible to radical reinterpretation.[FN81] Thus, if audiences come into the [pg593] theater expecting another Hamlet-is-an-indecisive-fellow performance, that is how they most likely will interpret and critically evaluate the performance that they see. They are quite likely in the present interpretive context to fail to understand what the actor playing Hamlet is doing if he were to present my "play about a play" interpretation. They might very well miss the joke entirely. On the other hand, if someday an audience comes into the theater expecting to see a comic play about a tragic play - that is, when my radical reinterpretation becomes commonplace ]FN82] — that audience might indeed consider a "straight" performance of Hamlet as an indecisive prince a mediocre piece of acting.

\section{JURISPRUDENCE AS AUDIENCE-PREPARATION}

Perhaps the most difficult problems of audience pre-selection and preparation are not to be found in literature but rather in jurisprudence. Legislators (and framers of constitutions) have an unlimited number of words at their disposal, but they can use them only once, and what they say has significant consequences. A statute once enacted lays down the law until it is amended; and even if it is amended, the time gap between the original enactment and the amendment is governed by the once-only choice of words that the legislature passed.[FN83] Hence the problem is to precondition the audience so that the statutes will fall on friendly ears ("friendly" in the sense of likely to adhere to the intent of the legislators who enacted [pg594] the statute). [FN84] I contend that jurisprudence performs this preconditioning function. 
Jurisprudence consists of theories of interpretation of law: meta-interpretive theories that are supposed to stand apart from any particular body of law. A great deal of the effort that has gone into jurisprudence has been devoted to attempts to define "law." Many pragmatic attorneys and legal scholars dismiss jurisprudence on just this ground: all the theories seem to depend on how law is defined. Yet legal philosophers are acutely aware of this pragmatic dismissal of jurisprudence and thus strive to match their definitions as closely as possible to how lawyers and nonjurisprudential scholars ordinarily use the term "law." For the real aim of jurisprudence is not to define law, but to indicate the proper sources for judicial decisionmaking. Positivists, who want to constrain judicial decisionmaking, say that legislative commands constitute "law," and accordingly emphasize statutes as the only legitimate source for judicial decisions and deemphasize "common law" and custom. [FN85] Naturalists reverse these emphases because they are more comfortable in expanding the ambit of judicial decisionmaking. [FN86]

Jurisprudential theories can play a powerful rhetorical role in legal argument. In most cases, a statute will apparently favor one side [pg595] more than the other. If the statute seems to favor the plaintiff, then the plaintiff will be helped rhetorically if she uses legal positivism in the construction of her arguments. In the same case, the defendant will be helped rhetorically if he uses natural law in the construction of his arguments. The justification I give to my Jurisprudence classes for studying a subject that is not on the multistate bar exam is that knowledge of jurisprudential theories will help lawyers in selecting and constructing legal arguments on any side of any case, and in understanding and refuting arguments of opposing counsel.

Yet writers of legal philosophy would probably say that this pragmatic use of jurisprudence is at best a by-product of their theories. The professed aim of their theories is to get at the truth of what law is. Any positivist believes that positivism, with appropriate amendments, is true and naturalism is false; naturalists believe the opposite. Both positivists and naturalists believe in interpretation as fervently as Stanley Fish disbelieves in it.

There is a curious utility in legal theorists believing that their jurisprudential theories are true rather than just rhetorical; such a belief makes the theorists better rhetoricians. For it is invariably more persuasive to argue that something "is" the case rather than to argue that something "ought to be" the case. The conflating of "is" and "ought" [FN87] has resonated throughout natural-law theory as a peculiarly effective form of rhetoric. [FN88]

The position I want to take is that if an audience believes a given jurisprudential theory, that audience has forfeited a few of its degrees of interpretive freedom, and that if the legislature knows this fact about its audience, it may be able to use jurisprudence to its advantage.

Let us consider the classic jurisprudential example invented in 1958 by H. L. A. Hart in his debate with Fuller - a statute that forbids you [pg596] to take a vehicle into a public park. [FN89] Hart said that this statute, like any statute, has a "core" message: because an automobile is clearly a vehicle, you cannot take one into the park.[FN90] Hart's insistence that one can tease a core meaning out of the word "vehicle" has led some commentators to derive half-truths from the Hart-Fuller debate:

every post-Realist law student ought to know that when the town council declares that there shall be no vehicles in the park, it becomes no easier to tell whether it meant to bar wheelchairs, bikes, or a statue of a general in his jeep if we simply think harder about what the word vehicle means. [FN91]

This interpretation is accurate only insofar as its conclusion (that to "think harder" about the core meaning will not get us anywhere) is concerned. But it misses the main point of the Hart- 
Fuller exchange. For one thing, Hart never claimed that the penumbral cases, such as wheelchairs or bikes, could be derived from the word "vehicle"; he only made that claim as to core instances. The most he claimed with respect to penumbral applications of the statute was that a court has unfettered discretion in a case of first impression to include or exclude such applications within the statute. [FN92] Subsequent courts would lack such discretion only because of the rule of stare decisis. For another thing, Fuller never claimed that a statue of a general in a jeep was or was not a penumbral instance like wheelchairs or bikes. Fuller's far more profound invention deserves quotation:

What would Professor Hart say if some local patriots wanted to mount on a pedestal in the park a truck used in World War II, while other citizens, regarding the proposed memorial as an eyesore, support their stand by the "no vehicle" rule? Does this truck, in perfect working order, fall within the core or the penumbra? [FN93]

[pg597] To some extent the failure of some commentators to understand Fuller's point was due to the inaccurate way Fuller himself put the question. He should not have asked whether the truck falls within the core or the penumbra. The fact is that Fuller invented a Godelian undecidable proposition precisely within Hart's "core" formula. Godel, it will be recalled, proved that there are some mathematical propositions (actually, an infinity of them) that can neither be proved nor disproved within a mathematical system of at least enough complexity as to include ordinary arithmetic. [FN94] Any existing language qualifies as a system of at least as much complexity as ordinary arithmetic, and hence Godel's proof applies to legal, textual, and linguistic demonstrations. [FN95] Fuller's example of the truck demonstrates the undecidability of the case (between local patriots and other citizens) given an indisputable core-instance "vehicle." [FN96] In the post-Fish era, [pg598] we can reinterpret Fuller's conclusion to be the following: what Hart thought was non-problematic (the core idea of a "vehicle") turns out [pg599] to be a mini-theory (a theory about vehicleness), and that mini-theory, like all theories, is subject to radical reinterpretation. In short, Fuller punctured the theory balloon thirty years ago.[FN97]

The foregoing analysis reduces Hart's positivistic core-penumbra distinction to two propositions: (a) what we think of as falling within the core of the statute could be subject to radical reinterpretation, [FN98] and (b) what we think of as falling within the penumbra [FN99] is the typical "arguable" case (even if not solvable by staring at the word "vehicle" [FN100]). I contend that, as to (a), no interpretive theory of what constitutes the core can help us. But as to (b), we can dispute whether any of the following (a list I made up a while ago) should or should not come within the statute: "Sherman tanks, flying saucers that land within the park, hydrofoils, motorized play-pens, or visitors from outer space who have wheels instead of legs for their personal locomotion [and drink gasoline]." [FN101] Not to mention, of course, the usual penumbral cases: bicycles, tricycles, scooters, skateboards, baby carriages, and motorized wheelchairs.

Because these penumbral cases are disputable (not as radically disputable as the core cases, contrary to what Dworkin says [FN102]), it may [pg600] make a difference whether the interpreter is a positivist or a naturalist as to how many of these examples will seem to him to be barred by the statute. And that indeed is my thesis in this Part. I suggest that it is simply more likely that a positivist guard on duty at the entrance to the park (or a court reviewing the guard's determinations) will bar more of the foregoing penumbral cases — and of all other imaginable penumbral cases — than would a naturalist guard. 
This result accords with commonplace experience. We are all familiar with literal-minded officers or bureaucrats. These are the persons who spot something that looks like a vehicle and promptly bar it from the park. They will often do very unreasonable things. They might for instance bar an ambulance, a fire truck, [FN103] or a police car [FN104] from entering the park. They will certainly be more likely to [pg601] bar bicycles, scooters, and motorized wheelchairs. They make these decisions because they have absorbed positivist jurisprudential theory. [FN105]

If guards, police officers, or lower courts are known to have absorbed positivist theory, a legislature could exploit this fact in order to reduce the degrees of interpretive freedom its statutes will encounter. Using the word "vehicle" will thus cut a wider swath with respect to the penumbral cases that I have listed. A legislature bent upon excluding as many of those penumbral cases as possible will be well advised to use the word "vehicle" if it knows in advance that its most likely interpretive community will consist of positivist-minded guards and courts.

But there are two important codicils to append to this thesis, lest it be radically misinterpreted. First, I am not claiming that the legislature will be better served by having positivist (or, alternatively, naturalist) interpreters. For instance, if the legislature has no intent to exclude ambulances, fire engines, and police cars from the park, then it may be ill-served by the "no vehicles" sign when that sign is interpreted by positivists. If the legislature does decide to use the "no vehicles" sign and yet wants to allow fire engines and ambulances into the park, it will, as we have seen, be better served by guards and courts who are imbued with naturalist jurisprudential theory. If, however, the legislature knows in advance that its interpretive community will consist mostly of positivists, and it still wants to load the odds in favor of ambulances and fire engines being allowed into the park, its best strategy would be to write those specific exceptions into the statute. Of course, the inclusion of specific exceptions requires the legislature to have foreseen the panoply of desired exceptions in advance. Such a list of exceptions will not do the entire job if the legislature has not also thought of groundskeepers' trucks and tractors. A positivist guard will bar those from the park even though a heated argument will undoubtedly ensue between the guard and the caretaker, who will insist that "of course" he should be allowed into [pg602] the park to tend to the grounds. But the guard will reply, "Since you're not one of the approved exceptions, you can turn your truck around and take up your gripe with the city council." (If the legislature added the abbreviation "etc." to the list of approved exceptions, the result might contribute to the mental destabilization of positivistic park guards.)

My second codicil is that there is no a priori reason why positivists rather than naturalists will take a wider view of any given statute. [FN106] Consider a statute that says "no automobiles in the park." A naturalist guard is more likely than a positivist guard to interpret this statute as also barring trucks, campers, and motorcycles.[FN107] Although the positivist (but not the naturalist) would bar an automobile temporarily commandeered as an ambulance, on the whole the naturalist would take a more inclusive view of the statute's scope, reasoning that automobiles must have been barred for some legislative reason and hence that other automobile-like things should be barred if that inferred reason also applies to them.

Hence, all I am claiming is that there will be a tendency toward varying breadths of interpretation depending upon the general jurisprudential theory of the interpretive community. A legislature that knows in advance what that general jurisprudential theory is likely to be will have a slightly more precise way of communicating the message it wants to communicate than a legislature that is oblivious to this theory. In particular, if there is a reigning jurisprudence among the judges of the 
day, the legislature will be more effective in writing its statutes if it knows what this jurisprudence is and how to exploit it. [FN108] Indeed, if there is any jurisprudence among judges, or [pg603] even any theory of statutory interpretation among judges, legislators would be well advised to know what it is.

\section{CONCLUSION}

My thesis has thus been a modest one. I do not claim for jurisprudence the role of ensuring faithful reception of the legislature's message, for that is impossible. At best, jurisprudential theory only reduces the degrees of interpretive freedom, and then only probably, not necessarily. Yet if that is all I have accomplished here as a positive matter, the more significant thesis of this Article is that all theories of statutory interpretation can only do that much and no more. In this sense, as a negative claim opposing all formalistic theories of legislative interpretation, my thesis may disprove more than it proves. I hope it will not be considered less constructive for that reason.

\section{FOOTNOTES}

*Copyright 1989 Anthony D’Amato, Professor of Law, Northwestern University. I would like to thank my colleagues Carol Rose and Ian Ayres for their general comments, and Charlotte Crane and Michael Durst for their suggestions on the part of this article dealing with taxation.

** Numbers in the form [pg561] etc. refer to the page numbers in the original text.

[FN1 See S. Fish, Is There a Text in This Class? (1980); Dworkin, My Reply to Stanley Fish (and Walter Benn Michaels): Please Don't Talk about Objectivity Anymore, in The Politics of Interpretation 287 (W. Mitchell ed. 1983); Fish, Interpretation and the Pluralist Vision, 60 Tex. L. Rev. 495 (1982); Fish, Working on the Chain Gang: Interpretation in Law and Literature, 60 Tex. L. Rev. 551 (1982); Fish, Wrong Again, 62 Tex. L. Rev. 299 (1983) [hereinafter Wrong Again]; Fish, Dennis Martinez and the Uses of Theory, 96 Yale L.J. 1773 (1987) [hereinafter Uses of Theory]; Fish, Still Wrong After All These Years, 6 Law \& Phil. 401 (1987); Fish, Don't Know Much About the Middle Ages: Posner on Law and Literature, 97 Yale L.J. 777 (1988) [hereinafter Don't Know Much]; Solum, On the Indeterminacy Crisis: Critiquing Critical Dogma, 54 U. Chi. L. Rev. 462 (1987); Spann, Deconstructing the Legislative Veto, 68 Minn. L. Rev. 473 (1984).

[FN2 ]The counterstrategy is impossible if one accepts Gadamer's hermeneutics: the meaning of a text always surpasses its own author, because the author is himself imbedded in a historical moment within his interpretive tradition. See H. Gadamer, Truth and Method 259 (2d ed. 1985). For a delicate filigree on this theme (addressed to aesthetics but just as applicable to a statute or a judicial precedent), see Gadamer, Aesthetics and Hermeneutics, in H. Gadamer, Philosophical Hermeneutics 95 (D. Linge ed. 1976).

[FN3] See Moore, The Semantics of Judging, 54 S. Cal. L. Rev. 151, 246-70 (1981).

[FN4] And as such contained many defects of question-begging and reification-problems that seem to arise when authors write in sentences that convey eternal truth and impersonal authoritativeness. 
[FN5] Professor Fish's position on "intention" is that "[t]here is only one way to read or interpret and that is the way of intention; but to read intentionally is not to be constrained relative to some other (non-existent) way of reading." Fish, Don't Know Much, supra note 1, at 778.

[FN6] Indeed, positivism construes a judicial decision as legislative in nature; courts are considered to have been delegated a limited legislative competence in the penumbral areas of statutes. For a discussion and references, see A. D'Amato, Jurisprudence: A Descriptive and Normative Analysis of Law 118-41 (1984).

[FN7] When I refer in this Article to statutory interpretation, I mean to include constitutional interpretation as well.

[FN8] See works by Stanley Fish, supra note 1, as well as his forthcoming book, S. Fish, Doing What Comes Naturally (1989).

[FN9] For a good critique of recent attempts to formulate general principles of constitutional interpretation, see Fiss, Objectivity and Interpretation, 34 Stan. L. Rev. 739 (1982).

[FN10] They sometimes believe they are following explicit rules even though they are aware of the existence of equally valid rules compelling the opposite interpretation! Karl Llewellyn once published a revealing list of utterly contradictory rules of interpretation; one of those rules, or its opposite, will "justify" any desired interpretation. See Llewellyn, Remarks on the Theory of Appellate Decision and the Rules or Canons About How Statutes Are to Be Construed, 3 Vand. L. Rev. 395, 401-06 (1950).

[FN11] This issue recalls William James' famous question: Do we cry because we are sad, or are we sad because we cry? See W. James, 2 The Principles of Psychology 449-50 (1890). Although this was a heretical question when first asked, there now is empirical evidence that emotions are caused by feedback from physiological arousal, and that what we "think" about these emotions is in some sense an ex post facto rationalization. See R. de Sousa, The Rationality of Emotion 51-64 (1987). If this account is true of our innermost perceptions of ourselves, it is a fortiori true of the way our minds attach meaning to external phenomena such as texts.

[FN12] See, e.g., Holton, 'What, precisely, is "thinking"?' Einstein's answer, in Einstein: A Centenary Volume 153, 159-60 (A. French ed. 1979). An important step in Heisenberg's development of his uncertainty principle was a discussion he had with Einstein in 1926. According to Rosenfeld, Heisenberg's "attempt at arguing that a good theory ought only to operate with observable quantities had elicited from Einstein the pointed retort, which had made a strong impression on him: 'Only the theory itself can decide what is and is not observable."' Rosenfeld, Men and Ideas in the History of Atomic Theory, reprinted in Quantum Theory and Measurement 57, 58 (J. Wheeler \& W. Zurek eds. 1983).

[FN13] In his early writings and teaching, Professor Lon Fuller stressed the legislative "purpose" in statutory interpretation. See, e.g., Fuller, The Case of the Speluncean Explorers, 62 Harv. L. Rev. 616, 623-26 (1949). Later he became convinced that the legislature could not foresee how statutes would be interpreted: "The troublesome cases are in reality resolved not in advance by the legislator, but at the point of application. This means that in applying the statute [forbidding 'vehicles' in the public park] the judge or police sergeant must be guided not simply by its words but also by some conception of what is fit and proper to come into a park. . ." L. Fuller, Anatomy of the Law 59 (1968). My article can be viewed as an attempt to provide a synthesis of Fuller's early 
"purpose" thesis and his later "point of application" antithesis. I suggest that legislatures might not know how the statute will be interpreted, but might have an idea of the kinds of theories of interpretation the judges or police sergeants are likely to have in mind when they are called upon to "apply" the statute.

[FN14] For a good discussion which came out after I wrote the above, see W. Poundstone, Labyrinths of Reason 191-221 (1988).

[FN15] For particularly good accounts of the European theatre, see A. Brown, Bodyguard of Lies (1975) and R. Jones, The Wizard War (1978). A good general history of the Pacific theatre, using recently declassified materials, is J. Costello, The Pacific War (1981). Of the spate of recent books about Pearl Harbor and Midway, a good firsthand account is E. Layton, "And I Was There" (1985). I have yet to find a book that honestly recounts the extent to which American soldiers died at the hands of other American soldiers who-as the result of communications snafus-fired or dropped bombs upon them. These episodes are still a sanitized part of military history, available only from personal, unwritten accounts of military field officers.

[FN16] In the early days of the war, Japan sent their best and most experienced pilots on repeated missions. These pilots were accustomed to communicating with each other and coordinating their flying patterns. But after normal attrition, Japanese leaders discovered that the loss of their best pilots was too costly_air attacks were becoming noticeably less effective due to lack of coordination and communication. The policy then shifted to one of keeping their best pilots at home as trainers. But again no amount of advance training could prepare inexperienced pilots to deal with the ambiguities of communication and coordination. Finally, a mixed strategy (which had generally been employed by the United States from the very beginning) was adopted: send some experienced pilots out among the majority of inexperienced ones on any given mission, and keep some experienced pilots at home as trainers.

[FN17] For discussions of the role of cryptology in extraterrestrial communications, see Deavours, Extraterrestrial Communication: A Cryptologic Perspective, in Extraterrestrials: Science and Alien Intelligence 201 (E. Regis ed. 1985); Freudenthal, Excerpts from LINCOS: Design of a Language for Cosmic Intercourse, in Extraterrestrials: Science and Alien Intelligence 215.

[FN18] For further discussion of the plaque, see C. Sagan, The Cosmic Connection 16-33 (1973); Sagan, Sagan \& Drake, A Message From Earth, 175 Science 881 (1972). For a detailed description of the more extensive message (including recorded greetings and music) sent with the later Voyager probe, see C. Sagan, Murmurs of Earth (1978).

[FN19] The message itself might be a binary radio message, but cryptologists could easily decipher it if it is a direct encoding of the English language (in which any numerals can stand for any letter, so long as the numerals do not change in the course of the message). Of course, this would not be a "secret code" in the sense I used in the text accompanying notes 14-16, supra.

[FN20] This reasoning ultimately reduces to Quine's famous showing of the impossibility of a determinate "radical" translation, i.e., direct translation from an unrelated language without the aid of analogues arising from shared cultural elements. W. Quine, Word and Object §§7-16 (1960). Quine concludes that radical translation is indeterminate for even the simplest segments of language because the behavior associated with that segment is equally consistent with two or more English translations with different meanings. See id. $\$ 12$. What is more relevant to our discussion, radical 
translation could not proceed at all without the observation of associated behavior, which is impossible in the example in the text.

[FN21] Of course, the extraterrestrials' interpreting our broadcasts with sufficient accuracy even to attempt to deceive us in our own language requires their being able to observe the behaviors and contexts associated with segments of our language. Such a largely successful radical translation would otherwise be impossible, regardless of the extraterrestrials' intelligence. See supra note 20. The earth-extraterrestrial situation may not be entirely symmetrical, however: if the costs to us of their successful deception greatly exceed the costs to them of an unsuccessful deception, they can afford translation errors more than we can.

[FN22] I make this argument not as a frustrated writer of science fiction, but to note in all seriousness the possibility that sending messages into outer space might result in contacting a hostile intelligence. It is the starkest example I can think of to illustrate the point that for communication to make sense, the sender of the message ought in advance to know a great deal about the receiver of the message. Although Carl Sagan and others convinced the public to support the attachment of the message to the Pioneer probes, see, e.g., Sagan, Sagan \& Drake, supra note 18, I reserve the opinion that the project seems to have been fundamentally misconceived.

After I wrote the above, a student told me about an old "Twilight Zone" television episode in which a cryptologist attempted to translate a book written by seemingly altruistic visiting aliens. The book was entitled To Serve Man. As the cryptologist prepares to board ship for a visit to the aliens' planet, his assistant tells him that the book was a cookbook. R. Serling, "To Serve Man," The Twilight Zone (CBS television broadcast, Mar. 2, 1962). Damon Knight, the author of the short story on which the episode was based, recognized the unlikelihood of "serve" having the same double meaning in both English and the aliens' language, and "'tried to cover [himself] by having the narrator's friend remark that some of the idioms were very much like English."' M. Zicree, The Twilight Zone Compansion 237 (1982).

[FN23] See H. Putnam, Representation and Reality 75 (1988) ("Functionalists like myself or David Lewis recognize that an ascription of meaning to someone's 'representations,' an interpretation of someone's language (or thought-signs), must proceed simultaneously with the ascription of beliefs and desires to the person being interpreted." (footnote omitted)).

[FN24] N. Wiener, God \& Golem, Inc. 59-60 (1964).

[FN25] L. Wittgenstein, Philosophical Investigations, 9甲 68-70, at 33e (G. Anscombe trans. 1953). Wittgenstein adds: "Must the exclusion of the game with dice have come before his mind when he gave me the order?" Id.

[FN26 ] Fuller, supra note 13, at 625.

[FN27] Standard office humor contains something like the following dialogue:

BOSS: What reason can you possibly have to explain why you didn't do the work that I left for you this morning?

EMPLOYEE: Nobody told me to go ahead.

[FN28] Which, theoretically, is always true. Even if the sender is looking at the receiver, the sender cannot be certain about what the receiver is seeing, feeling, or thinking about. A close corollary of the impossibility of radical translation is the "private worlds" problem: that even two people 
who know each other and are looking at each other when they converse cannot be sure of what the other is hearing or understanding. See W. Quine, supra note 20, § 16 at 79.

[FN29] To be precise, she never learns what he "intends," but only learns what kinds of behavior on her part make him angry. She accordingly adjusts her behavior. While she uses his vocal instructions as one rough guide to predicting whether he will become angry if she does not do thusand-so, she may also use other signals_-his facial expressions, for instance.

[FN30] I am not talking about things like preambles to statutes, because the preambles themselves have to be interpreted-usually adding to the headaches of the statutory interpreter. No matter how artfully worded the preamble, there is always the question whether it should be given more weight or less weight than the accompanying statute in those cases where the preamble and the statute seem to conflict with each other. (Where they do not seem to conflict, the question of the preamble's role does not arise.) Additionally, how can we interpret the prologue without a prologue to the prologue? This is the "turtles all the way down" story. See Cramton, Demystifying Legal Scholarship, 75 Geo. L.J. 1, 1-2 (1986).

[FN31] V. Nabokov, King, Queen, Knave 1 (1968).

[FN32 Are there other possible ways to interpret this paragraph? Consider: (1) the entire episode is a dream; (2) the episode is taking place on a planet in another galaxy where iron pillars actually are alive and walk; (3) the observer writing the paragraph is the train itself, knowing that it itself is inanimate and viewing the animated surroundings.

[FN33] My favorite comment along these lines is the one made by Samuel Goldwyn from the deck of the Queen Mary as it left the New York pier on his wedding voyage to England. He shouted in his booming voice to the crowd on the pier, "Bon Voyage!"

[FN34] Cf. L. Wittgenstein, supra note 25, at pt. 1, \139 ("I see a picture; it represents an old man walking up a steep path leaning on a stick.-How? Might it not have looked just the same if he had been sliding downhill in that position? Perhaps a Martian would describe the picture so").

[FN35] I have no evidence for this conjecture, but I would be very surprised if Nabokov had not read the dialogue either in his student days at Cambridge (1919-1922) or in his residency in Berlin (1922-1937). Around 1934, when the Nabokovs were in Berlin and Mrs. Nabokov was working in the French embassy, she acted as an interpreter for Albert Einstein, who was then involved in an international pacifist movement. See A. Field, Nabokov: His Life in Part 199 (1977). Nabokov's fascination with relativity is clear from the extended discussion of time in his last novel Ada. V. Nabokov, Ada 535-63 (1969).

[FN36] Einstein, Dialogue on Objections to the Theory of Relativity, reprinted in Albert Einstein's Theory of General Relativity 99, 107 (G. Tauber ed. 1979). There is some evidence in the text of King, Queen, Knave that Nabokov was consciously parodying Einstein. Nabokov goes on to write:

[N]ot only did all this fall behind; the entire old burg in its rosy autumn morning mist moved as well: the great stone Herzog in the square, the dark cathedral, the shop signs - top hat, a fish, the copper basin of a barber. There was no stopping the world now. In grand style houses pass by, the curtains flap in the open windows of his home, its floors crackle a little, the walls creak, his mother and sister are drinking their morning coffee in the swift draft, the furniture shudders 
from the quickening jolts, and ever more rapidly, more mysteriously, travel the houses, the cathedral, the square, the sidestreets.

V. Nabokov, supra note 31, at 2.

Einstein's "Dialogue" had mentioned a church steeple: "[W]hy then did the church steeple near the train not topple when together with the environment it sustained the shock-why do such results of the jolt manifest themselves so one-sidedly only in the train ... [?]" Einstein, supra, at 106.

[FN37] Einstein, supra note 36, at 107 n.1.

[FN38] I discussed the disutility of intentional and motivational analysis in D'Amato, Psychological Constructs in Foreign Policy Prediction, 11 J. Conflict Resolution 294, 294-95 (1967).

[FN39] See M. Minsky, The Society of Mind §§ 30.3-30.5 (1986).

[FN40] It is not even necessary for me to make this claim about Nabokov as a real person. It suffices for me to say that we may attribute an intent to the author of the book irrespective of the question - which we can never know - whether Nabokov actually had that intent. The author of the book is not equivalent to Nabokov the person (contrary to Bertrand Russell's famous "identity" between Scott and the author of Waverley), because if we take Nabokov's view of a book as a conversation between author and reader, the "author" in that sense is the fictional character who wrote the book. For a self-parody of this point, see V. Nabokov, Lolita 313-19 (1955) (author's postscript); cf. V. Nabokov, Pale Fire (1962) (editor and annotator of the book is a fictional character).

This same line of reasoning can apply to statutory interpretation. For instance, if we talk about the original intent of the framers of the Constitution, it may be less valid to look at the biographies of each framer to figure out his constitutional philosophy and then try to combine them, than it would be to assume an Aggregate Mind that came together in Philadelphia and worked out the text of the Constitution. The latter — even though it borders on the fictional-may get us closer to "intent" (if that is our goal) than any amount of speculation about the real lives, motives, and desires of the individual framers.

[FN41] A similar point is made in a different context by R. Rorty, Is There a Problem About Fictional Discourse?, in Consequences of Pragmatism, 110, 135-37 (1982). Rorty says that all the ontological work of the linguistic philosophers (from Russell to Quine) has acted to set up the possibility of novelists and poets "violating the space defined by the proscenium arch." Id. at 135. Writers such as Borges, Nabokov, and Wallace Stevens achieve many of their word-and-object effects largely (Rorty unpersuasively assets) only because of the background myth implanted by linguistic philosophers. "What is most distinctively modern in modern literature depends for its effect upon [philosophical] straight men. ..." Id. at 136.

[FN42] For a good philosophical discussion of the importance of probabilistic statements as opposed to certainty statements, see W. Salmon, Scientific Explanation and the Causal Structure of the World 184-205 (1984).

[FN43] It was the academic year of 1958-59, and the royalties that poured in for his best-selling Lolita would lead the next year to his retirement from teaching. A. Field, supra note 35, at 278.

[FN44] Many of Professor Nabokov's lectures have been published (but, alas, not as they were delivered; the publications have been from his own lecture notes); altogether, they will serve admirably to convey this master novelist's interpretive theories. See V. Nabokov, Good Readers and 
Good Writers, in Lectures on Literature 1-6 (F. Bowers ed. 1980); V. Nabokov, The Art of Translation, in Lectures on Russian Literature 315-21 (F. Bowers ed. 1981); V. Nabokov, Lectures on Don Quixote 1-4 (F. Bowers ed. 1983) (fiction vs. reality).

[FN45] I can still recall the implied criticism in his voice as he stretched out the pronunciation of the word "de-fin-i-tive."

[FN46] Our knowledge of the "real" Madame Bovary acts as a sort of theory about the fictional Madame Bovary. But like any other theory, the theory itself may blind us to the truth.

[FN47] Fiction is necessarily modeled on the real world but is not a depiction of the real world. Cf. H. Putnam, Reason, Truth and History 1-5 (1981) (contending that no text is a depiction of the real world unless the author intended it to be so). Putnam's assertions engendered a great deal of controversy, and in a recent book Putnam has attempted to modify his notion of intentionality, moving both toward a holistic view of interpretation and a greater acceptance of Quine's views about meaning. See H. Putnam, Representation and Reality (1988). The California Court of Appeals failed to appreciate the point that a work of fiction may come close to reality, but that the slight gap between fiction and reality makes all the difference, in a poorly reasoned decision regarding the novel Touching. See Bindrim v. Mitchell, 92 Cal. App. 3d 61, 76-78, 155 Cal. Rptr. 29, 38-39, cert. denied, 444 U.S. 984 (1979) (affirming for plaintiff in libel case; defendants unsuccessfully argued that libelous publications had to contain false statements of fact, and since the publication at issue was fiction, its characters were factual representations only of fictional characters and not of real persons).

[FN48] By "text" I mean any text or any number of texts. Thus if we think we can determine the intent of Congress by looking at the "legislative history" of a statute, all we are doing is adding a lot of text to the statute itself (text consisting of committee reports, Senate debates, and so forth). The question persists: what was the intent of Congress when it created all this additional legislative history? What was the intent of the persons who spoke on the floor of the Senate? Indeed, were certain items slipped into committee reports in order to falsify the legislative history and thus achieve an "interpretation" favored by a particular interest group? As Professor Fish said in a recent essay, "Once words have been dislodged as the repository of meaning in favor of intention, no amount of them will suffice to establish an intention since the value they have will always depend on that which they presume to establish." Fish, Going Down the Anti-Formalist Road, in S. Fish, supra note 8, at 11.

Generations of law students have been taught that the intent of Congress or the intent of the framers can be ascertained by poring over vast amounts of legislative history. They will probably never accept — despite the irrefutability of Fish's argument — that all that additional text cannot, as a matter of logic, tell us the intent behind even the simplest statute or constitutional provision.

[FN49] In class Nabokov would often become exasperated at the English translations we used, and on occasion would read us the text in the original language (for the cadence) and then render his own translation. Anyone so attuned to the nature of translation as Nabokov (he later gave the world a monumental translation of Pushkin's Eugene Onegin) would never have said that an author's intent is identical to the words the author used. The point is subtle, however, because of Nabokov's emphasis upon style. Style, he told us, was everything. How something was said was more important than what was said. Yet the style was a way to capture the image (that is, the image of the artist's world), and not a substitute for the image. 
Cf. L. Wittgenstein, supra note 25, at 9120 : "You say: the point isn't the word, but its meaning, and you think of the meaning as a thing of the same kind as the word, though also different from the word. Here the word, there the meaning. The money, and the cow that you can buy with it."

[FN50] Judge Posner posits a world of difference between the two. See Posner, Law and Literature: A Relation Reargued, 72 Va. L. Rev. 1351 (1986). Professor Fish argues that every reason Judge Posner adduces for the difference between law and literature is culturally contingent and not in the least necessary. See Fish, Don't Know Much, supra note 1.

[FN51] Our understanding of the Nabokov text quoted above, supra note 31 and accompanying text, depends upon our assumption that the text is describing the real world (albeit relativistically or existentially). Because the work of fiction by definition cannot be checked against any real train station, the passage in the novel is open to the strange interpretation that in the "world of the novel" trains stand still while train stations move backward. The "world of the novel" is an artificial construct, and it can be "interpreted" any way the reader wants; hence, a literary interpreter can claim that in the world of the novel as she sees the world, certain strange things are happening that the ordinary reader misunderstands because the ordinary reader mistakenly assumes that the world of the novel is the real world.

In conversations and letters I have exchanged over the years with Professor Alfred Appel, who is one of the foremost students of Nabokov, we have talked about how the population of the artificial world of the novel is sometimes made up of characters from other novels. There is a rich vein of literary interpretation waiting to be mined in this regard. A twist on this theme is the brief appearance of Flaubert himself at Madame Bovary's bedside at the end of that novel-as interpreted by Nabokov. Professor Nabokov mentioned in class that by the end of the novel Flaubert had attained such empathy for Emma Bovary that he materialized in the novel to be at her bedside. We then ask: has the author made his appearance in the novel as a fictional, or a real, character? Consider Woody Allen's plunge into the world of Madame Bovary in W. Allen, The Kugelmass Episode, in Side Effects 41 (1980), which foreshadowed the surreal premise of his (rather unlikable) motion picture, The Purple Rose of Cairo, in which the hero steps out of a black-and-white movie and into the (technicolor) audience to romance a movie-struck fan, while the rest of the characters on the screen wait around impatiently for the hero to come back. A similar theme is far better realized in Pirandello's play, Six Characters in Search of an Author. See L. Pirandello, Six Characters in Search of an Author (J. Linstrum trans. 1979).

[FN52] Fish says,

It is not that we first read the statute and then know its purpose; we know the purpose first, and only then can the statute be read.

A sentence is never not in a context. We are never not in a situation. A statute is never not read in the light of some purpose. A set of interpretive assumptions is always in force. A sentence that seems to need no interpretation is already the product of one.

S. Fish, supra note 1, at 280, 284.

[FN53] Fuller, supra note 13, at 624.

[FN54] We have already seen that adding a preamble to the statute will not work. See supra note 30 . 
[FN55] The same sort of skepticism about judicial lawmaking was expressed by Jeremy Bentham in his various writings. See, e.g., J. Bentham, The Constitutional Code bk. 2, ch. 12, § 19, in 9 The Works of Jeremy Bentham 1, 502-04 (J. Bowring ed. 1962) (establishing procedures in model constitutional code whereby the legislature would be informed of and could monitor contested judicial constructions of statutes).

[FN56] Cf. Wittgenstein's remark, "[T]he application of a word is not everywhere bounded by rules." L. Wittgenstein, supra note $25,984$.

[FN57] Fish, Uses of Theory, supra note 1, at 1792 (1987).

[FN58] In the case of collapsible corporations, the higher tax is the income tax. The planner of the collapsible corporation wants to pay taxes at only the capital gains rates, which until the full implementation of the Tax Reform Act of 1986, 26 U.S.C. §§1-1501 (1982 \& Supp. V 1987), were significantly lower than the income tax rates. As I did my research on the subject, I could see that-given any court decision interpreting the collapsible corporations section-one could structure a more complex interlocking corporate structure (using, for example, subsidiaries and trusts) that would apparently take account of every objection raised in that court decision and yet achieve the tax planner's purpose of transforming ordinary income into capital gains. Literal compliance with the Internal Revenue Code and complete tax avoidance are available to any lawyer who is sufficiently ingenious and industrious and whose client has a sufficient financial motivation to avoid the tax.

[FN59] Universal tax avoidance does not take place because attorneys' fees for structuring complex transactions to avoid taxes are too high for most people. Yet whenever a particular tax avoidance scheme-one that is in literal compliance with the tax code-is publicized, typically either the Internal Revenue Service reconstrues the Code to void the scheme or Congress itself plugs the loophole. Plugging the loophole does not take away the opportunity for tax avoidance; it simply increases the costs of avoidance.

Large corporate buy-outs, acquisitions, and mergers are nowadays preceded by an advance Treasury ruling, spelling out the tax consequences of the deal. Even though the Treasury itself may not understand the Code, corporations are often content with obtaining such rulings because of the reduction of uncertainty. A lot of tax "law" is created in this process; it would be metaphysical to claim that the Treasury is somehow doing what Congress intended.

There are times when even Congress throws in the towel. Having passed the Tax Reform Act of 1986, Congress decided that it was unable to figure out in advance what tax practitioners would do with the subpart on asset acquisitions, and hence enacted Section 337(d), which delegates to the Secretary of the Treasury the power to "prescribe such regulations as may be necessary or appropriate to carry out the purposes of the amendments made to this subpart by the Tax Reform Act of 1986, including ... regulations to ensure that such purposes may not be circumvented through the use of any provision of law or regulations. ..." I.R.C. § 337(d) (West 1988).

[FN60] Loophole-plugging leads to problems of its own. The tax statutes become so convoluted by accretion of loophole-plugs that Internal Revenue agents cannot understand them-with a consequent loss of tax revenue.

[FN61] If the amount of potential tax is high enough, as in the case of estates of the very rich, ingenious (but expensive) tax planning can avoid most of the tax. This follows, I believe, from the 
invitation that Congress has held out to the courts to apply the tax code according to its words. Such a positivist approach virtually guarantees unlimited tax avoidance if the amount of money that can be avoided is large enough to pay for ingenuity on the part of lawyers who, simply in order to avoid paying taxes, will structure an estate many years before the testator dies. Hence, George Cooper has found that complex paper transactions suffice to enable the largest estates - those able to hire the best tax attorneys - to escape estate tax entirely. Indeed, the escape is so thorough that these estates often plan to pay a modest tax — say, five percent—simply to avoid public outcry that could lead to congressional reform. See Cooper, A Voluntary Tax? New Perspectives on Sophisticated Tax Avoidance, 77 Colum. L. Rev. 161, 163 (1977) ("It may be that the real certainties of this world are death and tax avoidance.").

[FN62] See D'Amato, Legal Uncertainty, 71 Cal. L. Rev. 1 (1983).

[FN63] 293 U.S. 465 (1935).

[FN64] See, e.g., Knetsch v. United States, 364 U.S. 361 (1960); Goldstein v. Commissioner, 364 F.2d 734 (2d Cir. 1966), cert. denied, 365 U.S. 1005 (1967); Commissioner v. Transport Trading \& Terminal Corp., 176 F.2d 570 (2d Cir. 1949).

[FN65] In spite of all that has been written about the business purpose doctrine, sham transactions, net effect, and the role of the court in looking through form to find substance, no authoritative, explicit rationale for judicial intervention to frustrate plans for tax avoidance has ever been given. The unpleasant conclusion remains that predicting the outcome of a concrete case in many of these areas, after a flood of decisions, remains often difficult and sometimes impossible.

Fuller, Business Purpose, Sham Transactions and the Relation of Private Law to the Law of Taxation, 37 Tul. L. Rev. 355, 389 (1963).

The "business purpose" theory only adds another layer of complexity to tax avoidance. Lawyers will have to structure transactions so that they will seem to have a business purpose. Like loopholeplugging, the "business purpose" doctrine serves only to drive up the cost of lawyering to achieve tax avoidance and therefore may raise tax revenues.

"Business purpose" is thus a theory chasing other tax theories. No amount of guessing a priori what kind of statute and what kind of statutory interpretive theory are best will do the tax job. That does not mean that the tax job cannot be done. Rather, taxation may be viewed as a huge, complex game: certain words (whatever they are) if enacted into a code will bring in a certain amount of money every year, and by tinkering with the words that amount of money either goes up or goes down. All is a matter of experimentation: What sorts of statutory wordings bring in the most revenue? Although no one seems to want to take this approach, it could be done with experimental controls and statistical validations, and the results could be eye-opening and counterintuitive (for example, is it possible that creating loopholes, rather than plugging them, will increase revenue?).

[FN66] See Levmore, Recharacterizations and the Nature of Theory in Corporate Tax Law, 136 U. Pa. L. Rev. 1019 (1988). Professor Levmore's valiant attempt to reduce this complex area of practice into rules as simple (but as vague!) as that recharacterizations must be "complete," "consistent," "brief," and "direct" may provide courts with new justificatory language but, I predict, will hardly make a substantive difference in the jungle of tax planning.

[FN67] Fish, Uses of Theory, supra note 1, at 1790. 
[FN68] The clearest examples of failure are those in which "applying the words" leads to absurd results. Judges and juries are reluctant to apply the words literally in these situations. Streetwise police officers "wink" at minor infractions. A policeman once told me that, riding around in his squad car he spots hundreds of minor traffic infractions a day, but he only writes tickets for the few serious or blatant ones.

[FN69] M. Kelman, A Guide to Critical Legal Studies 291 (1987).

[FN70] I tried to give some examples of outrageous hypotheticals in D'Amato, The Decline and Fall of Law Teaching in the Age of Student Consumerism, 37 J. Legal Educ. 461, 468-78 (1987).

[FN71] R. Dworkin, Law's Empire 45 (1986).

[FN72] Is a "book" something a "bookie" does when he "makes book?" Is a book what bridge players minimally attempt to achieve? Can an author store a "book" on her word processor? Such undecidable questions are the meat and potatoes of first-year law courses: Was the plaintiff an "employee" or an "independent contractor?" What is an "employee?" Was the defendant "negligent?" What is "negligence?" Was the writer "harmed" when she was libeled, even if the sales of her book skyrocketed after the libel? Is "harm" objectively determinable? Eventually, students are supposed to understand that the answers to these questions cannot be attained by staring at the words, although I can attest that not every student "gets it."

[FN73] I could have added, but didn't, that a "topologist" has been defined as a person who can't tell the difference between a doughnut and a cup of coffee.

[FN74] Dworkin, Law as Interpretation, 60 Tex. L. Rev. 527, 531 (1982).

[FN75] Fish, Wrong Again, supra note 1, at 303.

[FN76] Critics have been sharply divided as to the purpose of "The Murder of Gonzago" in Hamlet. But their discussion of purpose invariably ties the play-within-a-play to the tragedy-plot of Hamlet. I am suggesting that it fills a different role-stepping back from the tragedy-plot and pointing to what the play in its entirety is really about - the comedy-plot. In this interpretation, the reaction of the characters in the tragedy-plot to "The Murder of Gonzago" is brilliantly humorous - the same way Pirandello's Six Characters in Search of an Author is an extended humorous conceit; in both, the playwright detaches from the real play (the comedy) what seems to be going on in the artificial play (the tragedy). See L. Pirandello, supra note 51. Could Shakespeare possibly have had in mind, just for a little pun, a parallel between "The Murder of Gonzago" as a playlet and the star as a hamlet?

[FN77] Stanley Fish has convincingly argued that Coriolanus is a play about speech-acts. S. Fish, supra note 1, at 244-45. If Coriolanus is a play about performatives, Hamlet is a play about performances.

[FN78] Steve Martin's movie, Pennies from Heaven (Metro-Goldwyn-Mayer 1981), seems to me to be an attempt to be very funny about grossly depressing subject matter (it ostensibly takes place during the Great Depression). But the humor doesn't work; it may be a century or two ahead of its time. I can conceive of laughing at the movie, but when I saw it I actually found it quite sad. I can also imagine extraterrestrials landing in their flying saucers atop a movie theater, going inside, seeing Pennies from Heaven, and doubling over with laughter. 
Both Steve Martin and Lenny Bruce before him have been teachers of comedy. They have expanded our ability to understand and appreciate humor. For humor, I believe, is something we learn as it develops in our cultural history. A good test of the development of humor is to view some of the leading motion picture comedies of the 1930's. Many of their scenes (such as pratfalls, men dressed in women's underclothing, extended misunderstandings based on initial misidentifications) are distinctly unfunny today. These scenes represent static time-slices of comedy. Today we laugh more at comedy that is structural and dependent upon exquisite timing. Noel Coward's comedies, which were ahead of their time and underappreciated in the 1930's, are now coming into their own. Consider his masterpiece Private Lives. N. Coward, Private Lives (1930). There isn't a laugh-line in the whole play, but properly performed, its humor based on structure and timing makes it one of the funniest plays in the theatrical repertoire. This isn't a case of the interpretation of Noel Coward's play changing, for I imagine that Gertrude Lawrence and Noel Coward themselves performed it in the 1930's as well as anyone can today (with the possible exception of Maggie Smith). Rather, the audience has changed: we have moved toward Coward's conception of humor. Like Nabokov's work, Coward's plays are now "finding" their proper interpretive audience. (Indeed, to put a rubber band around this gratuitous mini-analysis, Coward's one-act Shadow Play, N. Coward, Shadow Play, in Tonight at 8:30: Plays by Noel Coward (1935), is distinctly a forerunner of the "black humor" of Lenny Bruce and Steve Martin.)

[FN79] For an example of this kind of bravura acting —although not in a comedy—consider Kate Nelligan's performance in the motion picture Eye of the Needle (United Artists 1981). She managed to play the role of an unknowing housewife to the murderer in the movie (Donald Sutherland) while at the same time signalling to the audience that she was fooling the murderer by playing a role. Ms. Nelligan brought this feat off so magnificently that it has apparently gone unnoticedthe best proof of perfect acting. (Recently critics have begun to accord recognition to Kate Nelligan's ability as an actress, but, so far as I am aware, without noting the difficulty of her task in Eye of the Needle and how she brought it off with apparent effortlessness.)

[FN80] Stanley Fish says that "no reading, however outlandish it might appear, is inherently an impossible one." S. Fish, supra note 1 , at 347.

[FN81] This is the point of supra note 78 concerning the growing receptivity of the comedies of Noel Coward. The point, however, is not a logically necessary one; the Lowenheim-Skolem proof would say in effect that we can add a description of the audience's mind-set to the text we're interpreting, and then radically reinterpret the entire package in an infinite number of ways. See infra notes 96 and 102.

[FN82] "[S]uch stuff As dreams are made of." W. Shakespeare, The Tempest, act IV, sc. i, lines 156-57.

[FN83] Of course, there are instances where courts have gotten into a running interpretive dialogue with legislatures. In Federal Baseball Club v. National League of Professional Baseball Clubs, 259 U.S. 200 (1922), the Court found (for reasons that seem archaic today) that professional baseball was not covered by the antitrust acts. Through the years, Congress had many occasions to amend the antitrust acts to cover baseball, but did not do so. In Toolson v. New York Yankees, Inc., 346 U.S. 356 (1953), the Court interpreted congressional silence as supporting the baseball exemption (despite what seems to me to be a determinative point that it takes more votes to pass a statute than to fail to pass one, and hence the failure to pass a statute in the years between the two cases cannot be accorded weight as if it were a positive enactment by Congress). Later the Court 
declined to hold that professional boxing should be given the same exempt status as baseball, despite the failure to discern any reason why the sports were different. United States v. International Boxing Club, 348 U.S. 236 (1955). For similar considerations in the tax area, see James v. United States, 366 U.S. 213, 230-35 (1961) (Black, J., concurring in part and dissenting in part).

[FN84] Sometimes this task seems beyond the ability of legislators. For example, Professor Karl Klare has demonstrated the Supreme Court's unwillingness to read and follow the legislative history of the Wagner Act insofar as Congress apparently intended to extend labor's role in management. See Klare, Judicial Deradicalization of the Wagner Act and the Origins of Modern Legal Consciousness, 1937-1941, 62 Minn. L. Rev. 265 (1978). This unwillingness may have been in part deliberate (designed to preserve fundamental capitalist relationships) and partly inadvertent (due to limited judicial ability to understand the issues). The story could be an object-lesson for Congress: if you want to legislate a social revolution, do not try to do it in one statute no matter how comprehensive it is, because the courts will either misunderstand or misconstrue it. Instead, engage in thoroughgoing tinkering with and amending of many statutes over a period of time; you have to weave the social revolution carefully into the fabric of the existing legal order. (This prescription, in turn, suggests a possible theoretical-rhetorical defense of the Supreme Court's interpretation of the Wagner Act: Congress's failure to pass the across-the-board legislation that would be necessary to alter fundamental social relationships suggests an interpretation that Congress didn't "really" intend as radical a Wagner Act as Congress said it intended!)

[FN85] Hence positivists stress the logical term "validity" in their theories. A statute is "valid" if it can be traced to the highest law in the land (the "rule of recognition" or the Constitution). A judicial decision is "valid" if it passively applies the statute to cases that fall within the core meaning of the statute. See H. Hart, The Concept of Law 97-107 (1961).

[FN86] See L. Fuller, The Law in Quest of Itself 31-32 (1940) (custom); Fuller, Human Interaction and the Law, 14 Am. J. Juris. 1 (1969) (diversity and breadth of "law").

[FN87] Despite the pains Hume took to distinguish between the two. See D. Hume, 2 A Treatise of Human Nature bk. 3, pt. 1, § 1 (T. Green \& T. Grose eds. 1909) (1739-40).

[FN88] See, e.g., G. Hegel, Natural Law 75-79 (T. Knox trans. 1975) (1801-02) (criticizing Kant's account of practical reason on similar grounds); cf. C. Haines, The Revival of Natural Law Concepts 323-49 (1930) (giving examples of how natural rights theorists have employed the rhetoric of objective validity in a variety of contexts). Nearly all of the great eighteenth century political theorists were rhetorical masters at demonstrating that their political agendas were simply descriptive of political forces currently in place.

[FN89] Hart, Positivism and the Separation of Law and Morals, 71 Harv. L. Rev. 593, 607 (1958); see H. Hart, supra note 85, at 125-26; Fuller, Positivism and Fidelity to Law-A Reply to Professor Hart, 71 Harv. L. Rev. 630 (1958).

[FN90] Hart, supra note 89, at 607. For an extended analysis of the Hart-Fuller exchange on this point with reference to cybernetic theory, see A. D'Amato, supra note 6, at 133-39.

[FN91] M. Kelman, supra note 69, at 12.

[FN92] H. Hart, supra note 85, at 123-32. 
[FN93] Fuller, supra note 89, at 663. The example I use in my Jurisprudence classes concerns Professor H. L. A. Hart himself attempting to enter the public park with his book The Concept of Law tucked under his arm. The guard on duty says:

GUARD: You cannot take that into the park.

HART: Why not? It's my book.

GUARD: The sign says "No vehicles in the park."

HART: But this book isn't a vehicle. For instance, it doesn't have a motor, you can't travel in it, it doesn't consume petrol. . . .

GUARD: Do you agree that I have no discretion in the matter? That I have to go by the exact definition of "vehicle?"

HART: Yes, I certainly agree to that.

GUARD (taking out a slip of paper from his pocket): Well, here it is. I copied it from the dictionary. It says that a book is a vehicle for ideas.

[FN94] Godel also "proved that is impossible to establish the internal logical consistency of a very large class of deductive systems — elementary arithmetic, for example — unless one adopts principles of reasoning so complex that their internal consistency is as open to doubt as that of the systems themselves." E. Nagel \& J. Newman, Godel's Proof 6 (1958). For discussions of Godel's proofs, see E. Nagel \& J. Newman, supra; D. Hofstadter, Godel, Escher, Bach: An Eternal Golden Braid 438-60 (1979).

[FN95] That Godel's proof applies to language and not just to mathematics has been shown in R. Smullyan, Forever Undecided: A Puzzle Guide to Godel 173-80 (1987).

[FN96] The "case" can be decided either way consistent with any legal theory. This result follows from the Lowenheim-Skolem mathematical proofs of the 1920's: that there is an infinite number of equally plausible theories to "explain" (or give the appearance of uniformity in) any given line of cases, as well as an infinite number that can "predict" the result in the next case any way that you want that result to come out.

Here is how any prior theory can be used to "explain" any desired result. Suppose we have the following sequence of numbers: 2, 4, 6. I ask you to give me the next number in the series. If you say "8," you have implicitly applied one possible theory about the sequence. But the LowenheimSkolem proofs showed, among other things, that any answer at all to my question can be shown to be the consequence of some theory. Suppose instead you give me the number 10. I then supply an appropriate theory: "the next number in the sequence is derived from adding the two preceding numbers, but when there is only one preceding number, add it twice." Following this formula, $2+2$ $=4 ; 2+4=6 ; 4+6=10$, Q.E.D. Suppose you pick a much stranger number, such as $72 / 3$. Again I provide a theory that produces the sequence 2, 4, 6, 7 2/3. The theory is: "the next number in the sequence is derived from putting the preceding two numbers together and dividing by the second one." Thus 2 and 4 become 24; divided by 4 gives a quotient of 6 . Next, 4 and 6 put together become 46; divided by 6 gives a quotient of 7 2/3, Q.E.D. Naturally, the stranger the number you supply for the last number in the sequence, the more complex the formula; but it follows from Lowenheim-Skolem that there will always be a formula (a theory) to account for any string of num- 
bers however long. Indeed, there will be an infinite number of formulae that will produce any string of numbers no matter how long the string.

My point is that if the Skolem-Lowenheim result is possible in mathematics-a deductive, precise system - it is a fortiori possible in common-law adjudication. No matter how many cases are given, there is an infinite number of explanatory verbal theories that fully explain their results. No matter how many cases are given as precedents, there is an infinite number of theories that will produce the "next" decisional result any way that you want that result to come out. Naturally some of these theories will be staggeringly complex, but the simple ones are not more likely to be "right." In mathematics there is no a priori assumption that the simpler of two theories is more likely to be right; mathematics itself is an invented discipline and hence simplicity cannot reflect any natural feature of mathematics. Paradoxically enough, even though law is supposed to reflect a real social system, the simpler of two legal theories is more likely to be vague or ambiguous! (For instance, we can say of a great many Supreme Court results that "there was a violation of the Due Process Clause," but that theory_although simple and elegant_-tells us a lot less than more complex verbal theories.)

For references to the Lowenheim-Skolem proofs, see infra note 102.

When this article was going to press, I noticed a reference by Professor Schauer to a previous use in the legal literature of the sequence-of-numbers demonstration. See Schauer, Easy Cases, 58 S. Cal. L. Rev. 399, 427 (1985), citing Tushnet, Following the Rules Laid Down: A Critique of Interpretivism and Neutral Principles, 96 Harv. L. Rev. 781, 821-24 (1983). Professor Tushnet showed that several different numbers were possible successors to the sequence $1,3,5,7$, although he did not credit the Lowenheim-Skolem theorem. Professor Schauer then proceeded to "rebut" Professor Tushnet's answers by providing, inter alia, the following choices: (g) $16^{37}$, 138 ${ }^{9}$; (h) .000000000027, 3.1415926535; (i) Reggie Jackson, Babe Ruth; (j) Cleveland, Newark; (k) none of the above; (l) all of the above. Professor Schauer concludes that these answers are "clearly incorrect." He is clearly mistaken. Lowenheim and Skolem proved that, given any sequence of numbers, a formula can be found (indeed, an infinite number of formulae can be found) that yields those numbers in precisely that sequence. A formula can be derived (complex, though it would be) that would yield 1, 3, 5, 7, .000000000027, 3.1415926535,. . . All the other numbers suggested as possible answers could be added to this sequence, proving (l) true. Option (k) is also provable; we provide a formula that yields none of the sequential numbers offered by Tushnet or Shauer. As for (i), the answer depends upon what we mean by "correct." We can find a formula that yields: 1, 3, 5, 7, Reggie Jackson, Babe Ruth . . . if we take a position on what we mean by "correct." If we mean, "numerically correct," and we translate the letters in the names Reggie Jackson to their numerical equivalents (and these numerical equivalents can be any numbers - such as the numerical place in the alphabet of the individual letters, or their Godel number, or any other number) — then we can find a formula that yields those numbers in proper sequential order. Or if we translate 1, 3, 5, and 7 into letters, we can do the same thing; we can invent a formula (a part of which might be, for example, "whenever you have a 'g' preceded by a vowel, add another ' $g$ ' but when you have a 'g' preceded by a consonant add an 'i'") that correctly produces the letters in the proper sequence. Perhaps if Professor Tushnet had indicated that his demonstration had been proven by Skolem and Lowenheim for all sequences and that there were an infinity of possible solutions, Professor Shauer would not have fallen into the (mathematical) trap. 
[FN97] Fuller's writing is incredibly opaque. (He had the same problem as a teacher.) Yet he tried as hard as he could to be clear. He is still the object of severe misinterpretation, yet struggling with a Fuller text well repays the effort. For a good essay on the difficulty of reading Fuller and the misunderstandings of many commentators, see Teachout, The Soul of the Fugue: An Essay on Reading Fuller, 70 Minn. L. Rev. 1073 (1986).

[FN98] See, e.g., Fuller's "truck" example and my "book" example of supra note 93 and accompanying text.

[FN99] Actually, there is a third category-falling outside the penumbra. The line between penumbra and nonpenumbra is as problematic as the line between penumbra and core, as I suggested in A. D'Amato, supra note 6, at 132-35.

[FN100] Fuller at one time thought it could be solved by reference to the statute's presumed purpose. See supra note 13.

[FN101] See A. D'Amato, supra note 6, at 137.

[FN102] See supra notes 71-73 and accompanying text. The idea of theory as after-the-fact rationalization was rigorously proved in mathematics by Leopold Lowenheim and Thoralf Skolem, who published their results in the early 1920's. What is now known as the Lowenheim-Skolem theorem states that for any axiom system one may choose to characterize any mathematical set (e.g., the positive whole numbers), there is an infinite number of other interpretations that are drastically different and yet also satisfy the axiom system. Thus, for every theory one has that seems to characterize certain facts, there is an infinite number of other theories that exactly characterize the same facts, many of which are drastically different from the original theory. See M. Kline, Mathematics: The Loss of Certainty 271-73 (1980). For example, if we take one Supreme Court case-or ten, or all of them-and fashion a theory, no matter how simple or complex, that "explains" the case or line of cases - other radically different theories can be constructed that exactly explain the same case or line of cases. Generalizing further from Lowenheim-Skolem, any interpretation of anything whatsoever is only one of an infinite number of equally accurate interpretations. Anything I see can be described in an infinite number of radically different ways. Anything I do can be interpreted in radically different ways from the way I interpret what I do or any observer interprets what I do. As summarized by Kline,

suppose one adopts a system of axioms for a theory of sets and one intends that these axioms should permit and indeed characterize non-denumerable collections of sets. One can, nevertheless, find a countable (denumerable) collection of sets that satisfies the system of axioms and other transfinite interpretations quite different from the one intended. Id. at 271.

The final blow to certainty was Lorenzen's later proof that a set which is denumerable in one level may be non-denumerable in another. See S. Korner, The Philosophy of Mathematics 154 (1960).

[FN103] Against the objection that such cases do not come up-that police do not bar fire trucks-intrudes the reality that a firefighter's union might raise the issue in a motion for an injunction. In Buckoke v. Greater London Council, [1971] Ch. 655, 2 All E.R. 254 (C.A.), Lord Denning was faced with precisely this problem. The union wanted to stop the practice of fire engines ignoring red traffic lights. The traffic statutes contained no exception for fire engines. Lord Denning 
held that fire engines, ambulances, and police cars may "shoot the lights." In true positivist fashion, he acted as a mini-legislature: "[W]e have grafted an exception on to the strictness of the law so as to mitigate the rigour of it." Id. at 670, 2 All E.R. at 259.

[FN104] I do not claim that positivist-minded guards will necessarily bar police cars, only that they may have a tendency to do so. If they do not bar police cars, they are not as likely as naturalists to have a ready theory to explain why they are not barring police cars. They may simply regard police cars as "exceptional" with respect to all regulations. See supra note 103. Moreover, their decision to let in a police car may be followed by a decision to bar an ambulance or fire truck. To the observer this would constitute irrational behavior, but the positivist guard may simply be trying to exclude as many vehicles as possible!

[FN105] An extreme example was the reaction of Gestapo and Nazi military officers to anything resembling an official document. Raoul Wallenberg exploited this rampant positivism in Budapest when he forged hundreds of Swedish passports and successfully utilized them to rescue Jews from Eichmann's extermination attempts in 1945. See Von Dardel v. Union of Soviet Socialist Republics, 623 F. Supp. 246, 249 (D.D.C. 1985); K. Marton, Wallenberg 81-87 (1982).

[FN106] More generally, what we today regard as a positivistic explanation itself may change in the course of time, so that fifty years from now the reactions I ascribe to positivist receivers of the legislative message may well be universally believed to be exemplary of non-positivist receivers. As Professor Fish might put it, the word "positivism" is just as subject to reinterpretation (even radical reinterpretation) as any other word.

[FN107] Compare Fish's point about Milton's "Samson Agonistes." The poem is now said to be about Christ "because he is nowhere mentioned. Such an argument seems to fly in the face of the rules of evidence, but in fact it illustrates something very important about evidence: it is always a function of what it is to be evidence for, and is never independently available." S. Fish, supra note 1 , at 272 .

[FN108] If the legislature is Congress and the statute is a major one whose constitutionality is sure to be tested in the Supreme Court, Congress clearly should take into account the jurisprudential theories of the existing Supreme Court justices in choosing the wording of the statute. 